\title{
Heterogeneity of Agents and Exchange Rate Dynamics: Evidence from the EMS
}

\author{
Eelke de Jong, * \\ Willem F. C. Verschoor* \\ and \\ Remco C.J. Zwinkels*
}

July, 2006

\begin{abstract}
$\underline{\text { Abstract }}$
We develop and estimate a dynamic heterogeneous agent model for the EMS period. Our empirical results suggest that the existence of heterogeneous interacting agents is indeed a possible explanation for the dynamics of exchange rates during the EMS; we find strong evidence in favor of our model using in- and out-of-sample tests. Moreover, we show that the heterogeneous agent model outperforms the random walk in out-of-sample forecasting in all country/period combinations. Finally, we study the dynamic limit properties of the estimated non-linear system.
\end{abstract}

Keywords: Heterogeneous expectations; The European Monetary System; Non-linear modelling; Agent-based finance

\section{JEL classification: F3, G12}

* Nijmegen Center for Economics (NiCE), Nijmegen School of Management, Radboud University Nijmegen, the Netherlands.

Correspondence address: Radboud University Nijmegen, Nijmegen School of Management, NiCE, P.O. Box 9108, 6500 HK, Nijmegen, the Netherlands. Phone: +31 (24) 3615454; e-mail: w.verschoor@fm.ru.nl.

We gratefully acknowledge helpful comments from Paul De Grauwe as well as participants at the June 2006 Workshop on Economic Heterogeneous Interacting Agents in Bologna, and the December 2005 Australasian Banking and Finance Conference meetings in Sydney. 


\section{Introduction}

The exchange rate models that emerged in response to the breakdown of Bretton Woods fixed-parity system in the early 1970s are without exception based on the notion of rational expectations (Muth, 1961) and a representative agent. It is increasingly evident, however, that traditional exchange rate modeling based on the efficient market rational expectations paradigm is rejected by the data. ${ }^{1}$ Several empirical anomalies have been uncovered over the years. One of the most widely stated empirical anomaly relates to the existence of the exchange rate disconnect puzzle, i.e. the exchange rate appears to be disconnected from its underlying fundamental process. For instance, the findings of Goodhart (1989) and more recently Faust et al (2003) contradict the efficient market rational expectations model, which implies that the majority of changes in exchange rates occurs when there is no observable news in the fundamentals. Other anomalies relate to the existence of excess volatility, fat tails of the distribution of exchange rate returns and volatility clustering (Flood and Rose, 1995; de Vries, 2001; Lux and Marchesi, 2000).

Guided by this evidence, which was difficult to rationalize in existing exchange rate models, three different modeling approaches of the exchange rate have emerged. The first one uses the Obstfeld-Rogoff $(1995,1996)$ REDUX framework of dynamic utility optimization of a representative agent. These micro-founded macro models assume rational expectations, but are more thorough in the micro foundation compared to the former exchange rate models. A second approach highlights the importance of the market microstructure theory in explaining the complex short-term behavior of the exchange rate (Evans and Lyons, 2002). Using order flow as a proximate determinant, they develop a model that is strikingly successful in accounting for realized exchange rate changes. In their analyses, they show that the order flow conveys dispersed information and that the distribution of information is an important determinant in short-run exchange rate movements. Moreover, the large volumes in the exchange rate market are explanatory for short-term movements and an indication that agents have different information or process information differently. As shown by Fan and Lyons (2001), informative trades are mixed with uninformative trades, indicating that market efficiency crucially depends on how markets accomplish

\footnotetext{
${ }^{1}$ Well-known examples of the rational expectations efficient market model is the monetary model, the Dornbusch model (Dornbusch, 1976) and the portfolio balance model.
} 
the difficult task of aggregating dispersed information. Finally, a third approach recognizes that heterogeneous agents have different and changing beliefs about the behavior of the exchange rate, thereby introducing non-linear features in the dynamics of the exchange rate. This approach was initiated by Frankel and Froot (1987) and further developed in the context of financial asset pricing. For instance, Brock and Hommes $(1997,1998)$ model trader-heterogeneity in a dynamic heterogeneous agents model with trader interaction and switching believes. Their approach differs from the fundamental models in that it explicitly models different types of boundedly rational behavior.

The third insight highlights the role of the heterogeneity of economic agents' expectations and seems promising in explaining the dynamics of asset prices, including the exchange rate (see de Long et al., 1990; Frankel and Froot, 1987; Brock and Hommes, 1998; Lux and Marchesi, 2000; Hommes, 2000). For instance, heterogeneous agent models are able to replicate the characteristics of exchange rate returns; volatility clustering, fat tails of the distribution of returns and the absence of first-moment predictability and long-run mean reversion are replicated by De Grauwe and Grimaldi (2005, 2006). Verification of the heterogeneous agent models, however, has only been done by either simulations or analytical derivations - both methods are elaborately presented in De Grauwe et al. (2004). The advantage of this approach is that it allows us to study the mechanics of the model in a purely deterministic way; it gives a clear view on the effect of the mechanisms in the model. The disadvantage, however, is that the model is not directly confronted with real-life financial data. It is therefore not certain whether the mechanisms formally described in the heterogeneous agent models are actually present in the dynamics of financial markets, despite the fact that the models are capable of reproducing the characteristics observed in exchange markets.

Although the heterogeneity of agents approach is intellectually satisfying, the heterogeneity model has hardly been estimated with empirical financial data because of the non-linear nature of the model that (mainly) arises from the existence of the mechanism that governs the switching between beliefs. Recently this issue has been explored either directly or indirectly by a number of papers. As an early example, Shiller (1984) introduces a model with rational smart money traders and ordinary investors and shows that the proportion of smart money traders varies considerably during the 1900-1983 period by assuming the effect of ordinary investors to be zero. 
Vigfusson (1997) and Ahrens and Reitz (2005) have circumvented the problem of the non-linear switching mechanism by replacing it by a Markov regime-switching approach. Baak (1999) and Chavas (2000) find significant evidence of agent heterogeneity in the beef market by applying a Kalman-filter approach. Winker and Gilli (2001) estimate a heterogeneous agent model indirectly by minimizing a loss function consisting of the kurtosis and $\mathrm{ARCH}$-estimates of the simulated data by adjusting the coefficients of the model. Reitz and Westerhoff $(2003,2006)$ estimate a model of chartists and fundamentalists with switching mechanism for exchange rates by assuming the weight of technical traders to be constant and the weight of fundamental traders to depend on the misalignment between the market and fundamental price. Boswijk et al. (2006) is the only example, to our best knowledge, that fully and directly estimates a heterogeneous agents model with switching mechanism; they simplify and rewrite the model of Brock and Hommes (1997) and estimate it for the S\&P500. Overall, the majority of the empirical studies finds evidence in favor of the heterogeneous agents models; both trader heterogeneity and switching believes are found.

This paper explores the relevance of the heterogeneity of agents' expectations, who use incomplete information and who have different beliefs about the future exchange rate. Our approach uses simple expectation formation rules, which form the asset price forming mechanism. The "fitness" of the rules is controlled ex-post by checking their risk-adjusted profitability; agents can switch to the more profitable rule. We extend the analyses of Boswijk et al. (2006) by estimating the heterogeneous agent model of De Grauwe and Grimaldi $(2005,2006)$ for the European Monetary System (EMS) exchange rates. Unlike previous foreign exchange rate studies, we avoid the problems of defining the 'true' fundamental exchange rate, on which there is no consensus in the literature and which may also change over time during a floating rate period (Manzan and Westerhoff, 2005). By using the central 'parity' rate as the fundamental rate, we estimate the model for the EMS-period, from March 1979 until December 1998. The EMS was literally an exchange rate target zone with narrow bands, such that there are movements in the exchange rate ${ }^{2}$, but still we have an observable "fundamental."

\footnotetext{
${ }^{2}$ Unlike the case of a fixed rate regime.
} 
Note that the intuition behind the heterogeneity model changes somewhat. ${ }^{3}$ Mean reversion does not necessarily have to be interpreted as fundamentalism, but as confidence in the target zone regime. ${ }^{4}$ True fundamentalists can also expect the exchange rate to move away from parity if they believe the central rate is not accurate and the exchange rate will move towards the actual economics based fundamental rate as perceived by traders. In this paper, we simply define fundamentalists as agents who condition their expectations on the central parity, irrespective of whether they are stabilizing or destabilizing for the target zone regime. Chartists, or technical analysts, in contrast, base their expectation on past returns. Furthermore, the behavior of market participants can be dependent on the position of the market rate in the band, comparable to the S-curve of Krugman (1991). Initially destabilizing chartists who believe the regime is credible might become stabilizing or revise their coefficients as the exchange rate gets close to the upper or lower band. In addition, the fundamentalists' expectation of mean-reversion might get stronger as the exchange rate moves closer to the band if they expect Central Bank interventions. Thus, mean reversion can be stronger if the expected gain is larger, so if the exchange rate is close to the band and the regime is credible, and vice versa.

The current study complements previous studies and makes several new contributions. Using a sample of eight EMS exchange rates for the period from March 1979 to December 1998, we find strong evidence in favor of the heterogeneous agent model. For seven countries, we find significant evidence of heterogeneous expectations; significant switching of believes is found for only two countries, but switching is significantly beneficial for the explanatory power of the model in seven cases. In addition, we show that the heterogeneous agent model outperforms the random walk in out-of-sample forecasting in all country/period combinations. Finally, we find that the limit behavior of the model for the total sample is generally stable, while it differs considerably per country and period for sub samples.

The remainder of the paper is organized as follows. Section 1 describes the three building blocks of the heterogeneous agent model, while Section 2 presents the methodology to empirically estimate the model. In Section 3 the estimation results are reported. In addition, Section 4 presents the forecasting ability of the model. Section 5

\footnotetext{
${ }^{3}$ An important feature of fixed exchange rate regimes is that parities are usually imperfectly credible and not permanent.

${ }^{4}$ The EMS exchange rate mechanism could very well lead to mean reversion in bilateral EMS exchange rates if the system succeeds in maintaining longer-run targets rates or central rates.
} 
discusses the deterministic behavior of our model, in particular the stability and type of limit behavior if we iterate the model forward. Finally, Section 6 concludes the paper.

\section{The model}

In this Section, we use a simple non-linear model of the exchange rate, which is very close to the approach proposed by De Grauwe and Grimaldi (2005, 2006). They model the exchange rate as a financial asset, while using the macro-economic fundamentals as an exogenous variable. The model consists of three building blocks. First agents decide on the optimal portfolio in a mean variance utility framework using simple expectations formation rules concerning the future exchange rate. Second, the actual exchange rate is formed by the weighted average of heterogeneous expectations and, third, the simple rules are evaluated ex-post by comparing their riskadjusted profitability. The following step consists of choosing a forecasting rule for the next cycle, based on past performance. We assume different types of agents, which we will call fundamentalists and chartists. ${ }^{5}$

\subsection{The investment decision}

We assume agents of different types $i$ depending on their beliefs about the future exchange rate. Each agent of type $i$ can invest in two assets, a domestic and a foreign one, and maximizes mean-variance utility given by the following equation:

$$
U\left(W_{t+1}^{i}\right)=E_{t}^{i}\left(W_{t+1}^{i}\right)-\frac{1}{2} \mu V_{t}^{i}\left(W_{t+1}^{i}\right)
$$

\footnotetext{
${ }^{5}$ Note that the chartists do not take into account information concerning the fundamental exchange rate and can be considered as pure noise traders (see De Long et al., 1990). For evidence that Chartism is used widely to make forecasts see Cheung et al., 1999 and Taylor and Allen, 1992. Neely and Weller (1999) show that this is also the case for the EMS period.
} 
where $W_{t+1}^{i}$ represents wealth of agent $i$ in period $t+1, E$ is the expectations operator of agent of type $i, \mu$ is the coefficient of risk aversion and $V_{t}^{i}\left(W_{t+1}^{i}\right)$ represents conditional volatility of wealth of agent $i$ in period $t+1$.

Agents can distribute their wealth between assets in the home country and assets in the foreign country; both pay a fixed rent. Next period's wealth is therefore equal to

$$
W_{t+1}^{i}=\left(1+i^{*}\right) s_{t+1} d_{i, t}+(1+i)\left(W_{t}^{i}-s_{t} d_{i, t}\right)
$$

where $i$ and $i^{*}$ represent home and foreign interest rates, $s_{t+1}$ is the exchange rate in period $t+1$ and $d_{i, t}$ is the amount of wealth invested abroad, denoted in foreign currency. Thus, the first term on the right-hand side of Equation 2 represents the value of the foreign portfolio in domestic currency at time $t+1$, while the second term represents the value of the domestic portfolio at time $t+1$. Next period wealth is dependent on the rates of return of the assets and the appreciation of the foreign currency. The investment decision is taken by choosing that amount of foreign assets $d_{i, t}$ that maximizes Equation (1). The optimal amount is found by substituting Equation (2) into (1) and maximizing with respect to $d_{i, t}$. The optimal amount of wealth invested abroad for investor type $i$ becomes:

$$
d_{i, t}^{*}=\frac{\left(1+i^{*}\right) E_{t}^{i}\left(s_{t+1}\right)-(1+i) s_{t}}{\mu \sigma_{t}^{2}}
$$

where $\sigma_{t}^{2}=\left(1+i^{*}\right)^{2} V_{t}\left(s_{t+1}\right)$. The amount of wealth invested abroad $d_{i, t}^{*}$ is thus dependent on the home and foreign interest rates, combined with both the heterogeneous beliefs about the future level of the exchange rate and its variance.

Total market demand for foreign assets at time $t$ is equal to the sum of individual demands, i.e.:

$$
\sum_{i=1}^{H} n_{i, t} d_{i, t}^{*}=D_{t}
$$


where $H$ is the number of different forecasting strategies, $n_{i, t}$ is the number of agents of type $i$ in period $t$ and $D_{t}$ is total demand for the foreign asset. Market equilibrium implies that market demand is equal to market supply $X_{t}$, which we assume to be exogenous. Thus,

$$
X_{t}=D_{t}
$$

where $X_{t}$ is the exogenous supply of foreign assets. For simplicity we assume the supply of foreign assets exogenous and constant; without loss of generality we can put $X_{t}=0$.

Substituting the optimal holdings into the market demand and then into the market equilibrium equation and solving for the exchange rate $s_{t}$ yields the market clearing exchange rate:

$$
s_{t}=\left(\frac{1+i^{*}}{1+i}\right) \sum_{i=1}^{H} w_{i, t} E_{t}^{i}\left(s_{t+1}\right)
$$

where $w_{i, t}=\frac{n_{i, t}}{\sum_{i} n_{i, t}}$ is the weight of agent of type $i$. Note that the current exchange rate is a function of expected future exchange rates. A way of interpreting this is that there is a Walrasian auctioneer; investors trade using market orders. At the beginning of the period, they choose their optimal demand of the risky asset to submit to the market maker. At the end of period $t$, the market maker fixes the equilibrium exchange rate $s_{t}$ that clears the market. The exchange rate is therefore always in equilibrium.

\subsection{Which strategy?}

The next step in our analysis is to specify how agents evaluate the fitness of the strategy they are using. We assume that agents use one of three rules, compare their (risk adjusted) profitability ex-post and then decide whether to keep the rule or switch to another one. Note that this is a boundedly rational setup. The model represents a complex non-linear world, such that expectations cannot be unbiased 
without infinitely accurate estimates of the coefficients and starting values of the model. The bounded rationality therefore does not come forward in non-accurate expectations, but lies in the fact that agents do not use all available information in forming expectations, while they do have costless access to that information. For example, agents know the expectations formed by both strategies because they compare profits. However, they do not take into account the existence of other agents when forming expectations, thus do not use all available information. The bounded rationality also shows from the fact that not all agents change strategy immediately once a certain strategy performs better than the other does in a given period. The number of agents using a given strategy evolves gradually over time, conditional on relative performance. On the other hand, agents do condition the choice of their expectation rule on past performance, which is relevant for maximizing utility. In addition, chartists are not showing herding behavior because the choice of expectation rule is not directly conditional on what other agents do, but on best forecasting performance. $^{6}$

This specification is more appropriate than the representative rational agent model since the hypothesis of rationality is rejected in all tests on survey expectations (see e.g. Cavaglia et al., 1993). Furthermore, introducing mutual conditioning in expectation formation creates the phenomenon of "infinite regress" (Townsend, 1983), i.e. the exchange rate depends on the expectations of other agents' expectations, which depends on the expectations of the expectations of other agents' expectations, and so on, ad infinitum. This leads to intractable mathematical problems except under very restrictive simplifying assumptions.

We use the concept of a switching mechanism as proposed by Brock and Hommes (1997) based on a multinomial logit setup. Such a mechanism consists of making the weights of the simple rules a function of the relative profitability of these rules, i.e.:

$$
w_{i, t}=\frac{\exp \left[\gamma\left(\pi_{i, t-1}-\sigma_{t-1}^{2}\right)\right]}{\exp \left[\gamma\left(\pi_{i, t-1}-\sigma_{t-1}^{2}\right)\right]+\sum_{j \neq i} \exp \left[\gamma\left(\pi_{j, t-1}-\sigma_{t-1}^{2}\right)\right]}
$$

\footnotetext{
${ }^{6}$ Indirectly, chartists do follow what other agents do because it is more profitable to be chartists the more chartists there are in the market. However, the expected level of return is the decision variable, not the number of chartists.
} 
which yields, after rewriting

$$
w_{i, t}=\frac{1}{1+\sum_{j \neq i} \exp \left[-\gamma\left(\pi_{j, t-1}-\pi_{i, t-1}\right)\right]}
$$

where $w_{i, t}$ is the fraction of agents of type $i$ in period $t$ and $\pi_{i, t}$ is the profit of strategy $i$. The parameter $\gamma$ measures the intensity of choice, the speed with which the technical traders (chartists) and fundamentalists revise their forecasting rules. This parameter measures the "status-quo bias" in the decision to switch to the more profitable rule (Kahneman et al., 1991); with $\gamma$ equal to zero agents are insensitive to the relative profitability of the rules, and are distributed evenly across strategies. On the other hand, with increasing $\gamma$ agents react more strongly to the relative profitability of the rules. In the limiting neo-classical case when $\gamma$ goes to infinity all agents react immediately to a difference in profitability, i.e. all choose the forecasting rule which proved to be more profitable in the previous period.

Brock and Hommes (1997) define profitability to be the total earnings (profits) on the optimal foreign asset holding. We define the profitability as the one-period excess return from investing in the foreign asset, multiplied by the optimal demand for the foreign asset. More formally,

$$
\pi_{i, t}=\left(s_{t}\left(1+i^{*}\right)-s_{t-1}(1+i)\right) \frac{\left(1+i^{*}\right) E_{t}^{i}\left(s_{t+1}\right)-(1+i) s_{t-1}}{\mu \sigma_{t}^{2}} .
$$

We have chosen for this setup because it is the most appropriate alternative. If we use utility instead of return, the performance is dependent on wealth. This is undesirable because traders are interested in the contemporaneous forecasting power of rules, not on past performance. Using only the one-period return is also less appropriate since this setup does not incorporate absolute differences in the magnitude of expectations, only the expected directions of change. 


\subsection{The forecasting strategies}

The functional form of the expectation formation rules can be adapted such that it fits the data best. The problem is that agents can use an infinite number of different rules; rationality can only take one form while bounded rationality can take infinitely different forms. The switching mechanism, however, works as a disciplining mechanism of the model; it prevents the modeler from inserting unrealistic forecasting strategies or strategies that are not being used. The weight of these strategies would go to zero, as the rules are not actually being used. Several different forms of expectations formation mechanisms have been uncovered over the years. In short, the expectation formation process can take different functional forms, depending on forecast horizon, sample period, and foreign exchange markets (see Allen and Taylor, 1992; Boswijk et al., (2006); Cavaglia et al., 1993; Frankel and Froot, 1987). We assume that there are three types of agents: Fundamentalists who condition their expectation on a comparison between the market and the fundamental rate and two chartists (technical traders) groups who condition their expectation on past exchange rate movements.

The fundamentalists condition their expectation on the difference between the market exchange rate and the central parity. Thus, the forecasting rule for the fundamentalists is

$$
E_{t}^{f}\left(\Delta s_{t+1}\right)=\sum_{k=1}^{n} \psi_{k}\left(s_{t-k}-s_{t-k}^{*}\right)
$$

where $s_{t}{ }^{*}$ is the fundamental exchange rate in period $t-1$ and $\psi_{k}$ the speed of adjustment parameter. ${ }^{7,8}$ This is a generalization of the fundamentalist rule proposed in De Grauwe and Grimaldi $(2005,2006)$; they assume $\psi_{k} \in<-1,0>$ such that fundamentalists provide a mean reverting dynamics. We do not assume this because it is unknown on forehand what the effect of fundamentalists will be in our market.

\footnotetext{
${ }^{7}$ Note that the expected future return depends on the previous misalignment and is not dependent on the current misalignment. The current exchange rate is formed by expectations of the future exchange rate, as comes clear from Equation 6. Therefore, the expected exchange rate cannot be a function of the current exchange rate, because this would render the equation unsolvable.

${ }^{8}$ De Grauwe and Grimaldi $(2005,2006)$ introduce information costs in the expectation formation for fundamentalists. However, because our "fundamental", the parity, is freely visible for all agents, we assume these costs to be zero.
} 
Empirical evidence suggests that exchange rates are mean reverting in the long run (see e.g. Mark, 1995). Therefore, agents have the opportunity to condition expectations on a high(er) number of lags.

The second group of agents in our model is technical analyst or chartist, using the serial correlation in the returns. Their forecasting rule is specified as

$$
E_{t}^{A R}\left(\Delta s_{t+1}\right)=\sum_{k=1}^{n} \alpha_{k}\left(\Delta s_{t-k}\right)
$$

where the chartists' expectation depends on the value of the parameter $\alpha$. With $-1<\alpha<0$ chartist expectations are stabilizing because agents expect a (partial) reversion of previous periods return. If $\alpha>0$ on the other hand, chartists have bandwagon expectations pushing the exchange rate constantly in a certain direction.

The first two groups are similar to those defined in De Grauwe and Grimaldi (2005, 2006); this is standard in the literature. We introduce a third group in order to generalize the model. The third group also uses a chartist strategy, based on the difference between the short term and long term moving average. Brock et al. (1992) introduces this strategy and demonstrate its relevance in financial markets; see also Chiarella et al. (2006) for the deterministic behavior of this rule in a heterogeneous agents setting. The forecasting rule is given by

$$
E_{t}^{M A}\left(\Delta s_{t+1}\right)=\sum_{k=1}^{n}\left(\lambda_{1, k} M A_{i, t-1}-\lambda_{2, k} M A_{j, t-1}\right)
$$

where $M A_{i, t}$ and $M A_{j, t}$ are the $i$ and $j$ months moving average of the level of the exchange rate, $i>j$. The strategy works destabilizing if $\lambda_{\mathrm{k}}>0$ as agents expect short run deviations from the long-term trend to persist; if $\lambda_{\mathrm{k}}<0$ the rule is stabilizing as agents expect the exchange rate to return to its long run moving average.

\section{The empirical estimation of the model}

The heterogeneous agent model described in Section 1 needs some adjustments before it can be estimated empirically. Furthermore, the target-zone 
character of our data sample demands some further adjustments to the model. The fundamental exchange rate in a simulation setup can be put equal to zero, such that it is possible to use the absolute difference between the exchange rate and the fundamental rate when simulating the model. However, the fundamental rate is not equal to zero in our setup, so we replace the misalignment $\left(s_{t}-s_{t}{ }^{*}\right)$ by $\left(s_{t}-s_{t}{ }^{*}\right) / s_{t}{ }^{*}$, representing the misalignment in percentages. Because the exchange rate is nonstationary as a result of the realignments, ordinary least square (OLS) estimates can be biased. For this reason, we replace the levels of the exchange rate in equation (6) with the percentage changes of the exchange rate. Next to the issue of non-stationarity, we encounter an endogeneity problem as the exchange rate return affects the misalignment whereas the misalignment affects the exchange rate return. ${ }^{9}$ In order to handle this issue, we use a two-stage least square (2SLS) setup. We therefore instrument the misalignment by the foreign exchange reserves of the home country, the realignments in the central parity and past values of the misalignment. Test results indicate that the endogeneity problem is solved with the instrumented variable.

For all three strategies, we assume that agents run a simple regression in order to obtain the optimal lags, in the sense of forecasting ability, for the misalignment, auto regressions, and moving averages. ${ }^{10}$ Because we want to verify whether the strategy of agents is conditional on the position of the exchange rate in the target zone, we add the absolute misalignment times the decision variable to the expectation formation functions in Equations (10)-(12). We can write the forecasting rule for the fundamentalists as follows:

$$
E_{t}^{f}\left(r_{t+1}\right)=\sum_{i=k, l} \psi_{1, i} \frac{s_{t-i}-s_{t-i}^{*}}{s_{t-i}^{*}}+\psi_{2, i} \frac{s_{t-i}-s_{t-i}^{*}}{s_{t-i}^{*}} \cdot \frac{\left|s_{t-i}-s_{t-i}^{*}\right|}{\left(1+b_{t-i}\right) s_{t-i}^{*}}
$$

with $k$ and $l$ the two optimal lags obtained from the exploratory regression by agents; $b_{t-i}$ the maximum bandwidth (in percentages) of the target zone and $r_{t}=\frac{s_{t}-s_{t-1}}{s_{t-1}}$. The second part of the second term on the right hand side thus

\footnotetext{
${ }^{9}$ The Haussman test indicates a highly significant endogeneity problem and the correlation between the misalignment and the residuals is significant.

${ }^{10}$ Agents are assumed to use two different lags. See the appendix for the optimal lag structure used by the agents.
} 
represents the current position of the exchange rate in the target zone vis-à-vis the maximum bandwidth (in percentages). The first coefficient, $\psi_{1, i}$, represents the direct effect of the misalignment on the expectation of fundamentalists, as in De Grauwe and Grimaldi $(2005,2006) ; \psi_{2, i}$ represents the effect the position of the exchange rate in the band on the expectation. If $-1<\psi_{1, i}, \psi_{2, i}<0$, fundamentalists are mean reverting, which becomes stronger as the exchange rate moves towards the upper or lower band. For both chartist strategies we also add the interaction term; the ARchartist forecasting rule becomes

$$
E_{t}^{A R}\left(r_{t+1}\right)=\sum_{i=k, l} \alpha_{1, i} r_{t-i}+\alpha_{2, i} r_{t-i} \frac{\left|s_{t-i}-s_{t-i}^{*}\right|}{\left(1+b_{t-i}\right) s_{t-i}^{*}}
$$

and the MA-chartist forecasting rule becomes

$$
E_{t}^{M A}\left(r_{t+1}\right)=\lambda_{1,1} M A_{i, t-1}-\lambda_{1,2} M A_{j, t-1}+\left(\lambda_{2,1} M A_{i, t-1}-\lambda_{2,2} M A_{j, t-1}\right) \frac{\left|s_{t-1}-s_{t-1}^{*}\right|}{\left(1+b_{t-1}\right) s_{t-1}^{*}}
$$

Equations (6), (8) and (9) together with the functional forms of the expectation formation mechanisms described in equations (13)-(15) can be combined to a single equation-framework and be estimated by non-linear least squares. ${ }^{11}$

Our database contains monthly bilateral exchange rates for currencies of countries that became EMS member in March 1979. For a number of years, prior to the formal adherence to the EMS, the Spanish peseta was informally kept within a +/6 percent band with respect to EMS currencies. The exchange rate data were obtained from Datastream. Even though daily and weekly rates are available, we choose to employ monthly data in order to avoid issues surrounding short-term noise such as the day-of-the-week effect with regard to exchange rate volatility (on which, see Hsieh, 1988). The interest rate series are call-money rates, which are largely provided by Datastream and the International Statistical Yearbook 2001. ${ }^{12}$ Our sample includes

\footnotetext{
${ }^{11}$ For an application of the estimation procedure see Boswijk et al. (2006).

${ }^{12}$ Experiments with long-term government bond yields did not affect our empirical results.
} 
238 monthly observations, ranging from March 1979 through December 1998, marking the introduction of the Euro ${ }^{13}$. The conditional variance of the exchange rate returns, obtained from a $\operatorname{GARCH}(1,1)$ estimation procedure, is used for the variance of the exchange rate $\sigma_{t}^{2}$.

\section{Empirical results}

Our first step consists of estimating the model without switching mechanism, so with constant fractions, such that the model becomes linear in the expectation formation functions of the three groups. The model simplifies to Equation (6), with $w_{i, t}=1 / 3 \forall i$, and the expectation formation functions in Equations (13), (14) and (15). The reason is that we first want to verify whether there is indeed significant evidence of heterogeneity on the foreign exchange market, before determining whether agents are switching between expectation formation techniques as well. Heterogeneity is defined as the contemporaneous presence of different expectation formation techniques in the market, i.e. one or more significant coefficients for more than one of the expectation formation Equations (13), (14) and (15). For the fundamentalists and AR-chartists we apply two lags; for the MA-chartists one. This setup removes all autocorrelation in the level and second moment of the residuals. The results of the estimation of this linear setup of the model are presented in Table 1.

\section{Insert Table 1}

Overall, Table 1 indicates that there is heterogeneity in the behavior of agents in the exchange rate market, given the contemporaneous significant existence of fundamentalism and one or two forms of chartism. The exchange rate returns are

\footnotetext{
${ }^{13}$ Spain and Portugal entered the EMS 1990 and 1993 respectively; they were included in the analysis as of the date of adherence to the EMS. Italy left the system for four years in the sample; these years are not included in the analyses.
} 
therefore affected by different beliefs concerning the future. Given the number of significant coefficients per group and the distribution over countries, the market seems to be dominated by fundamentalists and AR-chartists; MA-chartism is significant for only three countries in this setup. Furthermore, the general tendency seems to be for agents to be stabilizing, i.e. they expect either the exchange rate to return to the fundamental, the exchange rate to return to the long-run moving average, or past exchange rate returns to be reversed. Agents active on the market therefore seem to have a large amount of trust in the regime (the monetary authorities), as evidenced by the majority of negative coefficients.

For Italy, Portugal, and Spain, we observe evidence of all three groups given the one or more significant coefficients for all three expectation formation techniques; for Belgium, Denmark, France and Ireland two groups (fundamentalism and ARchartism) and for The Netherlands one group (AR-chartism). Fundamentalists are in general confident in the system in the short run given the negative $\psi_{1, \mathrm{k}}$ and/or $\psi_{2, \mathrm{k}}$ coefficients. That is, either they are directly stabilizing as $\psi_{1, \mathrm{k}}<0$ and thus expect a misalignment to be partially reversed in the next period, or they become meanreverting as the exchange rate moves towards the band of the target zone, so as $\psi$ $1, \mathrm{k}>0, \psi_{2, \mathrm{k}}<0$ and $\left|\psi_{1, \mathrm{k}}\right|<\left|\psi_{2, \mathrm{k}}\right|$. In other words, in the latter case agents expect the exchange rate to move away from the fundamental as the exchange rate is relatively close to parity, but expect the monetary authority to intervene as the exchange rate approaches the band of the target zone causing the exchange rate to return towards the central parity. In the long run, on the other hand, the signs of the fundamentalist coefficients $\psi_{1,1}$ and $\psi_{2,1}$ are predominantly positive, and are thus destabilizing. Agents expect the exchange rate to move away from the central parity in the long run $\left(\psi_{1,1}>0\right)$ and do not expect the monetary authority to intervene, but expect the motion away from the central parity to accelerate as the band of the target zone approaches ( $\psi$ $2,1>0)$.

The MA-chartist group is generally stabilizing given the negative estimates for $\lambda$. A negative $\lambda_{1, i}$ implies that agents expect a positive difference between the short run moving average and the long run moving average to decrease in the next period. A negative $\lambda_{2, \mathrm{i}}$ implies that agents expect the difference between short- and long-run moving averages to decrease quicker as the exchange rate moves closer to the band of the target zone. The $\lambda_{i, 1}$ and $\lambda_{i, 2}$ coefficients are not significantly different, implying 
that agents look at the difference between the moving averages; they do not look at the moving averages individually.

Moreover, the results of the AR-chartists are somewhat mixed concerning the conclusions about stabilizing/destabilizing expectations. This group is initially also stabilizing given the negative $\alpha_{1, \mathrm{i}}$ coefficients. A negative $\alpha_{1, \mathrm{i}}$ implies that an exchange rate shock is (partially) reversed in the next period. The $\alpha_{2, i}$ coefficients on the other hand, show a mixed image. A positive (negative) $\alpha_{2, \mathrm{i}}$ implies that agents expect the extrapolation (reversion) of shocks to be stronger as the exchange rate moves towards the band of the target zone. The total effect, so $\alpha_{1, i}+\alpha_{2, i}$, is positive for four countries and negative for four countries in both the short and the long run.

Boswijk et al. (2006) find significant evidence of two groups in the S\&P500 returns; fundamentalists, who expect mean reversion to the fundamental rate, and trend followers, who expect the deviation of the market price from the fundamental price to increase $\mathrm{e}^{14}$. The fact that we do not find destabilizing, or trend-following, behavior can be explained by the target-zone character of our sample; mean reversion in the EMS exchange rate is also found by Ball and Roma (1993), who estimate a jump-diffusion model, and by Anthony and MacDonald (1999), who use cointegration techniques. The model fit in terms of adjusted $R^{2}$ is somewhat lower in our case compared to Boswijk et al. (2006); 0.273 to 0.824 versus 0.77 to 0.82 . This can be explained by the fact that Boswijk et al. (2006) use yearly stock-market data compared to our monthly exchange rate data; both the lower frequency data and the other market usually yield a better fit.

In the next step of the analysis, we estimate the model including the switching mechanism defined by Equations (8) and (9). Table 2 gives the estimation results for the setup of the model with switching mechanism for the eight EMS countries ${ }^{15}$.

Insert Table 2

\footnotetext{
${ }^{14}$ Boswijk et al. (2006) rewrite the model in terms of the current Price/Earnings (P/E) ratio in deviation from the fundamental P/E ratio. It is assumed that both groups base their expectation on this deviation, while in our model expectations are based on different sources of information (i.e., deviation from the fundamental, AR-terms and MA-terms).

${ }^{15}$ Experiments with different forecasting rules for both the fundamentalists and chartists (adaptive and static expectations) and different profit-functions (mean square error, lagged profits) do not alter the results significantly.
} 
Overall, the intensity of choice parameter $\gamma^{*}$ is not significantly different from zero, which implies that agents do not change their expectation formation strategy through time, irrespective of its forecasting performance relative to alternative strategies. There are, however, three issues that potentially affect this result. First, the switching parameter $\gamma$ itself is not identified in the estimation procedure ${ }^{16}$; what is estimated, is $\gamma^{*}=\gamma / \mu$. The estimated intensity of choice is biased towards zero if agents are risk-averse $(\mu>1)$; also, given that two coefficients are estimated, the variance of the estimate of $\gamma^{*}$ is biased upwards. Both these effects might contribute to the fact that $\gamma^{*}$ is not found to be significantly different from zero. Second, large changes in $\gamma^{*}$ do not have a large effect on the weights $w_{i, t}$ because of the setup of the switching mechanism (Eq. 8). Terasvirta (1994), however, suggests that this effect is not relevant; significant heterogeneity in the regimes is a necessary condition. The third explanation could be the fact that all types of agents use the realized exchange rate returns to optimize the lag structure of their forecasting function. As a result, the profit differences might be relatively small, causing a low number of switches between strategies. Our results are directly comparable to the results of Boswijk et al. (2006), who also report insignificant estimates for the switching parameter.

For two countries, The Netherlands and Italy, we do find significant estimates for $\gamma^{*}$. Both coefficients are positive, which means that agents move away from strategies that are relatively profitable in period $t^{17}$ because they have learned that a certain strategy will not be profitable in consecutive periods. The size of the switching parameters is relatively small ${ }^{18}$, implying that agents only switch between strategies if the profit difference is large.

Generally, the signs and magnitudes of the $\psi, \lambda$ and $\alpha$ coefficients in Table 2 are comparable to the no-switching case in Table 1. Large, but not significant, changes only occur in cases in which the estimates are non-significant. In total, ten more coefficients are significant in the switching case compared to the non-switching setup. The expectation formation rules therefore fit the data better when the weight put on these rules is not constant through time.

\footnotetext{
${ }^{16}$ Note that $\gamma$ is not identified in the estimation. Focusing on the denominator of Equation (8), $\gamma\left(\pi_{i, t-1}-\pi_{j, t-1}\right)=\frac{\gamma}{\mu} \frac{\left(1+i^{*}\right)}{\sigma_{t}^{2}}\left(s_{t-1}\left(1+i^{*}\right)-s_{t-2}(1+i)\right)\left(E_{t-2}^{i}\left(s_{t-1}\right)-E_{t-2}^{j}\left(s_{t-1}\right)\right)$

${ }^{17}$ Or that $\gamma$ and $\mu$ are both negative. However, a negative risk aversion is highly unlikely.

${ }^{18}$ The switching parameter is usually set around one in simulations (De Grauwe and Grimaldi, 2006).
} 
We observe that the $R^{2}$ s $\mathrm{s}$ are higher in seven cases; likelihood ratio tests indicate that these differences are significant. The results indicate that the linearity assumption, i.e. constant fractions, is too rigid and that the switching mechanism is indeed beneficial in explaining movements in the returns. The switching of agents between strategies is therefore present in the data. This shows not only from the higher $R^{2}$, but also from the higher number of significant coefficients. In other words, although we do not find significant estimates for $\gamma^{*}$, including the switching mechanism does significantly improve the fit of the model. The issues noted above concerning the insignificance of the switching parameters therefore seem to have a significant effect on the results.

Insert Figure 1

Figure 1 plots the evolution of weights of the strategies over time. Weights are stacked, such that they add up to unity. The figures clearly illustrate that the switching parameters are relatively small in general; weights hover roughly around one third and two thirds ${ }^{19}$. There are no large changes in the distribution of population beliefs. Furthermore, none of the strategies is dominant for long periods on end. We do observe, however, persistence in the distribution of weights; beliefs do not bounce up and down per month, but change gradually. This is also the result of the relatively high status quo bias.

The weights in the price setting equation are relatively volatile for France and Portugal. For France this is the result of a relatively high $\gamma^{*}$, which makes agents sensitive to differences in forecasting ability. The high volatility for Portugal is mainly the result of the volatile exchange rate itself, which causes large potential differences in profits between the strategies. Therefore, although traders are not particularly sensitive to differences in profit, large deviations in performance trigger shifts in beliefs. Weights for Belgium and Ireland are relatively constant; for Belgium this is due to a relatively small $\gamma^{*}$. Ireland shows increased volatility in the weights around the 1993 crisis. The other countries are intermediate cases.

\footnotetext{
${ }^{19}$ Recall that weights are constant and equal to $1 / 3$ with $\gamma=0$.
} 
The volatility in weights of the two groups in Boswijk et al. (2006) is higher compared to what we find; weights range from zero to one and change more rapidly. This is a direct result of the much higher estimates for the switching parameter (-7.54 to -10.29). Furthermore, weights tend to be less extreme in our case because we have three groups; this decreases the probability of one group being dominant. De Grauwe and Grimaldi $(2005,2006)$ report that chartists are dominant (i.e. have a market share that exceeds 50\%) in a simulation analysis of the model. Our results indicate that ARchartists have the highest average weight, but this does not exceed 50\%. MA-chartists have the lowest average weight in general. Combined, however, chartists (so MA + AR) have a larger than 50\% market share. The simulation results of De Grauwe and Grimaldi (2005, 2006) are therefore partly corroborated. Allen and Taylor (1992) report that over $90 \%$ of foreign exchange market traders use some form of technical analysis. We do not find such strong chartist dominance.

\section{Insert Figure 2}

The effect of the intensity of choice parameter $\gamma^{*}$ is again clearly illustrated in Figure 2, where we present scatter plots of profit difference versus weight difference. In all scatters we observe that the higher the estimated $\gamma^{*}$, the stronger is the S-shape. A strong S-shape implies that the distribution of beliefs (Y-axis) changes rapidly as the profit difference diverges from zero (X-axis); traders are thus more sensitive to profit differences. As $\gamma^{*}$ approaches zero, the scatter first becomes a straight sloping line, then a straight flat line; agents respond sluggish to a difference in performance. The scatters are in general downward sloping, indicating that a positive difference in profits between strategies results in a negative difference in weights. In other words, agents move away from a strategy that is profitable in period $t$ because it is apparently less profitable in period $t+1$; this results from the positive estimate of $\gamma^{*}$. 


\section{Forecasting power}

Next to the in-sample performance of a model, the ability of a model to forecast exchange rates out-of-sample is considered an important criterion of its quality. The most famous example is of course Meese and Rogoff (1983), who showed that the news models from the 1970s performed worse than a simple random walk in terms of root-mean-squared forecasting error. To our best knowledge, only Clarida and Taylor (1997) and Mark (1995) have come up with a model that is able to outperform the random walk in out-of-sample forecasting during a floating rate regime. Mark (1995) shows that the exchange rate is mean-reverting to a monetary-model based fundamental by applying long-horizon regressions; Clarida and Taylor (1997) propose a vector error correction model and demonstrate the information content of the forward rate.

Results are somewhat more promising for the EMS period because there is in principle more forecastability in a target-zone than a floating rate system since market expectations are bounded by the upper and lower bands (given that the regime is credible). Aroskar et al. (2004) outperform the random walk model with an error correction model for all cases in the pre- and post-crisis period and for half of the cases in the crisis period. Mizrach (1992) presents better forecasting results with a multivariate nearest-neighbor than the random walk for the Italian Lira; FernandezRodriguez et al. (1999) present better root-mean-squared-error performance for their simultaneous nearest-neighbor predictor compared to the random walk for six out of nine currencies.

In order to verify the forecasting power of our model, we employ an alternative method compared to the papers stated above. Common practice is to apply a rolling regression technique, so to first estimate the model for a sub-sample, second create forecasts, third re-estimate the model with one extra observation, etc. We do not apply a rolling regression technique, but use the set of coefficients estimated over the total sample for all forecasts, with which dynamic forecasts are made by iterating the model forward for the appropriate number of periods. The reason is twofold; first, given the non-linear nature, the behavior of the model, and thereby the forecasts, is highly dependent on the magnitude of the coefficients (see Chiarella et al., 2002). Therefore, if we are interested in explaining movements in the market, it is essential to incorporate the coefficients representative for the market at hand. This is especially 
the case for the EMS because of the changing nature of the regime itself (realignments in the beginning years, stable middle period, and the crisis in the final years). Second, the model uses a relatively high number of coefficients, thus needs a relatively long sample period to be estimated properly.

Our method of forecasting demands more information concerning the coefficients, but uses less information regarding the variables compared to e.g. Meese and Rogoff (1983) and Mark (1995). In forecasting, we assume that the level of the fundamental (central parity), the bandwidth of the target zone, the interest rates, and the volatility remain constant, while Meese and Rogoff (1983) and Mark (1995) use future fundamental variables to generate forecasts. Our model thus does not use more information than the random walk model in this respect. Another advantage of our method is that forecasts can be formed over the complete sample, including the volatile beginning years of the EMS. This is not possible when applying the rolling regression technique because it needs a sufficiently large sub-sample in order to estimate the first set of coefficients. The comparison of forecasting ability between the random walk and heterogeneous agents model is therefore based on a larger number of observations when using our method, and can therefore be tested more rigorously.

The forecasting ability of the model is judged by comparing the mean absolute error (MAE) and mean squared error (MSE) of the forecasts formed by the heterogeneous agents model to those of the random walk model (i.e., no change). The significance of the difference in forecasting ability is tested by the Dybold and Mariano (1994) test statistic. The rectangular lag window is applied; with $k$ - 1 sample autocovariances for the $k$ step ahead forecast error. We focus on the 1,3, 6, and 12month forecast horizon for the eight countries. Table 3 presents the forecast errors made by the model divided by the forecast errors made by the random walk for the four forecast horizons and eight countries.

Insert Table 3

Overall, the results suggest that the heterogeneous agents model outperforms the random walk model in forecasting for all horizons; for the majority of countries both the MAE and MSE are smaller for our model than the random walk given the 
fact that the ratios in Table 3 are smaller than unity. Furthermore, the difference in forecasting ability is generally highly significant; only for Italy and the longer horizons of Spain is the significance somewhat less.

For both the MAE and MSE we observe that the forecasting power of the model vis-à-vis the random walk generally improves as the forecasting horizon increases up to six months, while it decreases again for the twelve months horizon; the ratios for the three (six) months horizon are smaller than the one (three) months horizon, and larger for the twelve months horizon than the six months horizon. This can be explained by the fact that the mean reversion of the exchange rate to the central parity creates a growing forecast error for the random walk as the forecast horizon increases, while it is incorporated in the heterogeneous agents model by the stabilizing expectations of the three groups. The change in this trend for the twelve months horizon could be due to the fact that realignments in the central parity are not incorporated in the forecasts made by the model. For Italy and Portugal there does not seem to be a clear tendency over the forecast horizons, while the results for Spain indicate that the shorter the horizon, the better the forecasting performance. This can be explained by the relatively high number of realignments for the southern-European countries.

Compared to the results of Mizrach (1992), who outperforms the random walk for the Italian Lira, we find forecastability for a broader set of countries participating in the EMS; we find relatively week results for the Italian Lira. Our results are directly in line with those of Fernandez-Rodriguez et al. (1999): significant outperformance of the random walk for the Belgian Franc, Danish Kroner, French Franc, Dutch Guilder, Irish Punt and Italian Lira, underperformance versus the random walk for the Portuguese Escudo and no significant results for the Spanish $\operatorname{Peseta}^{20}$. Aroskar et al. (2004) split their sample in a precrisis, crisis and postcrisis sample, while we only consider the total sample. However, we do corroborate their results for the pre- and postcrisis periods and show better results than the crisisperiod (which is also incorporated in our sample).

\footnotetext{
${ }^{20}$ Fernandez-Rodriguez et al. (1999) also include the British Pound Sterling in their analysis and find significant underperformance of their model versus the random walk forecast.
} 


\section{Stability}

The literature on heterogeneous agents models has been concerned with two main objectives. First, to try to replicate the stylized facts of financial markets such as heavy tails, volatility clustering, excess kurtosis by simulation techniques, see e.g. De Grauwe and Grimaldi (2005, 2006), Lux (1998), Lux and Marchesi (2000). The second objective is to derive analytically the deterministic behavior in terms of local stability or instability of the nonlinear dynamic models involved, see De Grauwe et al. (2004), Chiarella and He (2002), and Chiarella et al. (2002).

In this Section, we study the deterministic behavior of our model. More specifically, we investigate the stability and type of limit behavior of the model if we iterate the model forward, using the estimated set of coefficients. Figure 3 displays the limit behavior of the model for seven countries ${ }^{21}$, after iterating the model forward until convergence using the estimated coefficients for the total sample period.

\section{Insert Figure 3}

The majority of the countries converges to either a stable point or a stable limit cycle. Economically this implies that the target zone does not collapse, even without active central bank policy ${ }^{22}$; exchange rates do not diverge from the parity rate. The mean-reverting effect of the expectation formation strategies keeps the exchange rate within bands. The monetary authorities have shaped expectations in such a way in the 1974-1998 period such that the market controls itself afterwards.

The model converges to a stable equilibrium for France, given that the model converges to a fixed point. The exchange rate returns for Denmark, Portugal, and Spain are not on a sustainable path, the returns explode after forward iteration. Spain explodes within a small number of periods, but for Portugal and Denmark we see a relatively calm beginning, followed by one extreme negative for Portugal and followed by an explosive oscillative pattern for Denmark. For Spain and Portugal,

\footnotetext{
${ }^{21}$ The eighth country, Spain, explodes after two iterations

${ }^{22}$ Influence of the monetary authority is zero in the simulation; both parity and band remain constant and there are no interventions.
} 
this can be explained by the relative short in-sample period and the volatile exchange rate. For Denmark, however, with a stable exchange rate, the explosive behavior is completely the result of the nonlinear nature of the model; the explosive oscillations can occur as AR-chartists become dominant. The Belgian exchange rate becomes a two-period limit cycle; the Dutch exchange rate becomes a 19-period limit cycle; the Italian a 21-period cycle, and Ireland a 89 months cycle.

De Grauwe and Grimaldi $(2005,2006)$ present the sensitivity of the model to different coefficients. Especially the intensity of choice $\gamma$ and the extrapolation parameter of AR-chartists appear to be of great importance for the limit behavior of their model. We corroborate their findings given the fact that the countries that exhibit explosive behavior all have relatively high (absolute) estimates for the ARchartist extrapolation parameters $\alpha$; a value of $|\alpha|>1$ is explosive by definition.

Given that the exchange rates in the EMS show different periods, like the turbulent beginning years characterized by a high number of realignments; the stable middle part, and the turmoil in 1992 and 1993, it is interesting to look at the limit behavior of the model in sub samples, so using sets of coefficients estimated from sub samples. For this purpose, we estimate the model for a rolling window of one hundred observations $^{23}$, and check whether the limit behavior of the model for a certain country changes over time.

The characterizations of the limit cycles of the sub samples are presented in Table A1 of the Appendix. The stability of the deterministic system follows more or less the stability of the EMS itself. In the beginning years, we find a relatively high number of non-stable limits, so either explosive limits or highly complex cycles. The middle years of the EMS give a relatively high number of stable limit cycles and fixed points attractors. Around the 1992/1993 crisis, the number of unstable and explosive limits rises again. The changing limit behavior is an indication that expectation formation and investor behavior is not constant through time.

Insert Figure 4

\footnotetext{
${ }^{23}$ The first sub sample is thus 1979M03 - 1987M12, the second 1979M04 - 1988M01 etc. Spain and Portugal are omitted because of lack of observations.
} 
Figure 4 depicts some examples of the (complex) limit cycles we found. It is an illustration of the complex behavior that the simple model is capable of producing. In addition, it illustrates how the behavior of one single model can change dramatically when the coefficients change; different starting values or coefficient values have a much larger impact on this non-linear dynamic model than a standard e.g. monetary model ${ }^{24}$. It is a real-life example of the sensitivity analyses with respect to the coefficients as is done in De Grauwe and Grimaldi $(2005,2006)$. Outcomes of the model can differ significantly in reaction to a similar exogenous shock when coefficients are marginally different. Furthermore, even though the model produces a stable limit in most cases, this does not mean that this limit is reached in the same number of periods. As also comes clear from Figure 4, stability can be reached after a positive or negative swing, or stabilizing oscillations; in some occasions, it took the model more than ten thousands periods to converge to a stable equilibrium. Therefore, even if a number of sets of coefficients give a similar limit, short term dynamics can differ dramatically.

\section{Concluding remarks}

In this paper, we explored the relevance of the heterogeneity of agents' expectations, who use incomplete information and who have different beliefs about the future exchange rate. In particular, we extend the analyses of Boswijk et al. (2006) by estimating the heterogeneous agent model of De Grauwe and Grimaldi $(2005,2006)$ for the European Monetary System (EMS) exchange rates. By using the central 'parity' rate as the fundamental rate, we estimate the model for the EMS-period, from March 1979 until December 1998.

The empirical results suggest that there is heterogeneity in the behavior of agents in the EMS exchange rate market, given the contemporaneous significant existence of fundamentalism and one or two forms of chartism. Exchange rate returns are therefore affected by different beliefs concerning the future. One type of agents conditions its decisions on the distance to the central parity and two other types of agents condition their decision on past returns (based on auto regression and moving

\footnotetext{
${ }^{24}$ In linear models starting values are no issue at all.
} 
average). All groups have mean-reverting beliefs, so the fundamentalists expect the misalignment to decrease in the next period, AR-chartists expect a given period's return to be partially reversed the next period, and MA-chartists expect the exchange rate to return to its long run moving average. The coefficient governing the switching of believes is significant in two out of eight cases, but the model with switching mechanism does perform significantly better than the model without switching mechanism. Therefore, although the intensity of choice is not significantly different from zero in estimation, there are clues that agents switch between forecasting strategies. Moreover, all results are robust to the country and the functional forms of the expectation formation rules and the profit function.

The empirical relevance of the model is further demonstrated by its forecasting ability. Our estimation results show that the heterogeneous agent model outperforms the random walk model in forecasting future exchange rate returns in practically all the country/horizon combinations. Finally, we find that the limit behavior of the model for the total sample is generally stable, while it differs considerably per country and period for sub samples. 


\section{References}

Ahrens, R. and S. Reitz (2005). Heterogeneous Expectations in the Foreign Exchange Market: Evidence from Daily DM/US Dollar Exchange Rates. Journal of Evolutionary Dynamics 15(1): 65-82.

Allen, H. and M.P. Taylor (1992). The Use of Technical Analysis in the Foreign Exchange Market, Journal of International Money and Finance 11: 304-314.

Anthony, M. and R. MacDonald (1999). The Width of the Band and Exchange Rate Mean-Reversion: Some further ERM-based Results, Journal of International Money and Finance 18: 411-428.

Aroskar, R., S.K. Sarkar and P.E. Swanson (2004). European Foreign Exchange Market Efficiency: Evidence Based on Crisis and Noncrisis Periods, International Review of Financial Analysis 13: 333-347.

Baak, S.J. (1999). Tests for Bounded Rationality with a Linear Dynamic Model Distorted by Heterogeneous Expectations. Journal of Economic Dynamics and Control 23: 1517-1543.

Ball, C.A. and A. Roma (1993). A Jump Diffusion Model for the European Monetary System, Journal of International Money and Finance 12: 475-492.

Bilson, J. (1978). The Monetary Approach to the Exchange Rate: Some Empirical Evidence. IMF Staff Papers 25: 48-75.

Boswijk, H.P., C.H. Hommes and S. Manzan (2006). Behavioral Heterogeneity in Stock Prices, Journal of Economic Dynamics and Control, forthcoming.

Brock, W., J. Lakonishok and B. LeBaron (1992). Simple Technical Trading Rules and the Stochastic Properties of Stock Returns, Journal of Finance XLVII: $1731-1764$.

Brock, W. and C. Hommes (1997). A Rational Route to Randomness, Econometrica 69: 1059-1095.

Brock W. and C. Hommes (1998). Heterogeneous Beliefs and Routes to Chaos in a Simple Asset Pricing Model, Journal of Economic Dynamics and Control 22: $1235-1274$.

Cavaglia, S., W.F.C. Verschoor and C.C.P. Wolff (1993). Further Evidence on Exchange Rate Expectations, Journal of International Money and Finance 12: 78-98. 
Chavas, J.P. (2000). On Information and Market Dynamics: the Case of the U.S. beef Market. Journal of Economic Dynamics and Control 24: 833-853.

Cheung, Y., M. Chinn and I. Marsh (1999). How do UK Based Foreign Exchange Dealers think their Markets Operate? CEPR Discussion Paper 2230.

Chiarella, C. and X. He (2002). Heterogeneous Beliefs, Risk and Learning in a Simple Asset Pricing Model, Computational Economics 19: 95-132.

Chiarella, C., R. Dieci and L. Gardini (2002). Speculative Behaviour and Complex Asset Price Dynamics: a Global Analysis. Journal of Economic Behavior and Organization 49: 173-197.

Chiarella, C., Xuezhong He and C.H. Hommes (2006). A Dynamic Analysis of Moving Average Rules. Journal of Economic Dynamics and Control 30: 1729-1753.

Clarida, R.H. and M.P. Taylor (1997). The Term Structure of Forward Exchange Premiums and the Forecastability of Spot Exchange Rates: Correcting the Errors. The Review of Economics and Statistics LXXIX(3): 353-361.

Dornbusch, R. (1976). Expectations and Exchange Rate Dynamics, Journal of Political Economy 84: 1161-1176.

Dybold, F.X. and R.S. Mariano (1994). Comparing Predictive Accuracy, NBER Technical Working Paper 169.

Evans, M.D.D. and R.K. Lyons (2002). Order Flow and Exchange Rate Dynamics, Journal of Political Economy 110(1): 170-180.

Fan, M. and R. Lyons (2001). Customer Trades and Extreme Events in the Foreign Exchange, in: Mizen, P. (ed.) Monetary History, Exchange Rates and Financial Markets. Edward Elgar, Northampton.

Faust, J., E. Swanson and J. Wright (2003). Do Federal Reserve Policy Surprises Reveal Private Information about the Economy? Manuscript, Board of Governors of the Federal Reserve System.

Fernando-Rodriguez, F., S. Sovilla-Rivero, and J. Andrada-Felix (1999). Exchangerate Forecasts with Simultaneous Nearest-Neighbour Methods: Evidence from the EMS, International Journal of Forecasting 15: 383-392.

Flood, R.P. and A.K. Rose (1995). Fixing Exchange Rates: A Virtual Quest for Fundamentals, Journal of Monetary Economics 36: 3-37. 
Frankel, J.A. and K.A. Froot (1987). Understanding the US Dollar in the Eighties: The Expectations of Chartists and Fundamentalists, Economic Record 62: 2438.

Frankel, J.A. and K.A. Froot (1990). Chartists, Fundamentalists and Trading in the Foreign Exchange Market, American Economic Review 80(2): 181-185.

Frenkel, J.A. (1976). A Monetary Approach to the Exchange Rate: Doctrinal Aspects and Empirical Evidence. Scandinavian Journal of Economics 78: 200-224.

Grauwe, De. P., R. Dieci and M. Grimaldi (2004). Fundamental and Non-fundamental Equilibria in the Foreign Exchange Market. A Behavioral Finance Framework. CESifo Workingpaper No. 1431.

Grauwe, De. P. and M. Grimaldi (2005). Heterogeneity of Agents, Transaction Costs and the Exchange Rate, Journal of Economic Dynamics and Control 29: 691719.

Grauwe, De. P. and M. Grimaldi (2006). Exchange Rate Puzzles: A Tale of Switching Attractors. European Economic Review 50: 1-33.

Goodhart, C. (1989). The Foreign Exchange Market: A Random Walk with a Dragging Anchor, Economica 55: 437-460.

Hommes, C.H. (2001). Financial Markets as Complex Adaptive Evolutionary Systems, Quantitative Finance 1: 149-167.

Hsieh, D.A. (1988). The Statistical Properties of Daily Foreign Exchange Rates: 1974-1983, Journal of International Economics 24: 129-145.

Kahnemann, D., J.L. Knetsch and R.H. Thaler (1991). The Endowment Effect, Loss Aversion and Status Quo Bias: Anomalies, Journal of Economic Perspectives 5: 193-206.

Keynes, J.M. (1936). The General Theory of Employment, Interest and Money, London: MacMillan.

Krugman, P. (1991). Target Zones and Exchange Rate Dynamics, Quarterly Journal of Economics 106: 679-682.

Liu, P.C. (1996). The Effects of the Fundamentalists' and Chartists's Expectations on Market Survey. Applied Financial Economics 6: 363-366.

De Long, J.B., A. Shleifer, L.H. Summers and R.J. Waldmann (1990). Noise Trader Risk in Financial Markets, Journal of Political Economy 98: 703-738. 
Lux, T. (1998). The Socio-Economic Dynamics of Speculative Markets: Interacting Agents, chaos and the Fat Tails of Return Distribution. Journal of Economic Behavior and Organization 33: 143-165.

Lux, T. and M. Marchesi (2000). Volatility Clustering in Financial Markets: a MicroSimulation of Interacting Agents. International Journal of Theoretical and Applied Finance 3: 675-702.

Manzan, S. and F. Westerhoff (2005). Representativeness of News and Exchange Rate Dynamics. Journal of Economic Dynamics and Control 29: 677-689.

Mark, N.C. (1995). Exchange Rates and Fundamentals: Evidence on Long-Horizon Predictability, American Economic Review 85: 201-218.

Meese, R.A. and K. Rogoff (1983). Empirical Exchange Rate Models of the Seventies: Do They Fit Out of Sample? Journal of International Economics 14: 3-24.

Mizrach, B. (1992). Multivariate Nearest-Neighbour Forecasts of EMS Exchange Rates, Journal of Applied Econometrics 7: S151-S163.

Mussa, M. (1976). The Exchange Rate, the Balance of Payments and Monetary and Fiscal Policy under a Regime of Controlled Floating. Scandinavian Journal of Economics 78: 229-248.

Muth, J.F. (1961). Rational Expectations and the Theory of Price Movements. Econometrica 29: 315-335.

Neely, C.J. and P.A. Weller (1999). Technical Trading Rules in the European Monetary System, Journal of International Money and Finance 18: 429-458.

Obstfeld, M. and K. Rogoff (1995). Exchange Rate Dynamics Redux, Journal of Political Economy 103: 624-660.

Obstfeld, M. and K. Rogoff (1996). Foundations of International Macroeconomics, Cambridge MA and London: MIT Press.

Reitz, S. and F.H. Westerhoff (2003). Nonlinearities and Cyclical Behavior: the Role of Chartists and Fundamentalists. Studies in Nonlinear Dynamics and Econometrics 7(4), 3.

Reitz, S. and F.H. Westerhoff (2006). Commodity Price Cycles and Heterogeneous Speculators: A STAR-GARCH model, Empirical Economics, forthcoming.

Shiller, R.J. (1984). Stock Prices and Social Dynamics. Brookings Papers in Economic Activity 2: 457-510. 
Terasvirta, T. (1994). Specification, Estimation and Evaluation of Smooth Transition Autoregressive Models. Journal of the American Statistical Association 89: 208-218.

Townsend, R.M. (1983). Forecasting the Forecast of Others, Journal of Political Economy 91: 546-588.

Vigfusson (1997). Switching Between Chartists and Fundamentalists: A Markov Regime-Switching Approach. International Journal of Financial Economics: 291-305.

De Vries, C.G. (2001). Fat Tails and the History of the Guilder. Tinbergen Magazine 4: 3-6.

Winker, P. and M. Gilli (2001). Indirect Estimation of the Parameters of Agent Based Models of Financial Markets. FAME Research Paper 38. 


\section{Appendix}

Table A1: Optimal lags

\begin{tabular}{c|cccccc} 
& \multicolumn{2}{|c}{ Fundamentalist } & \multicolumn{2}{c}{ AR } & \multicolumn{2}{c}{ MA } \\
& $k$ & $l$ & $k$ & $l$ & $i$ & $j$ \\
\hline Belgium & 2 & 3 & 1 & 12 & 4 & 5 \\
Denmark & 1 & 2 & 1 & 2 & 7 & 8 \\
France & 3 & 4 & 8 & 9 & 9 & 10 \\
Netherlands & 1 & 20 & 13 & 16 & 9 & 10 \\
Ireland & 2 & 19 & 1 & 20 & 8 & 9 \\
Italy & 2 & 4 & 2 & 7 & 8 & 10 \\
Portugal & 3 & 9 & 2 & 16 & 2 & 3 \\
Spain & 1 & 10 & 8 & 10 & 1 & 2 \\
\hline Notes: Table A1 depicts the lags that optimize the forecasting power of the three \\
individual strategies, as used in the estimation procedure.
\end{tabular}


Table A2: Limit Behavior

\begin{tabular}{|c|c|c|c|c|c|c|c|c|c|c|c|c|c|c|c|c|c|c|c|c|c|c|c|c|c|c|c|c|c|c|c|c|c|c|c|c|c|c|c|}
\hline & 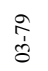 & $\frac{\hat{\tau}}{\dot{f}}$ & 홍 & $\begin{array}{l}\hat{\hat{े}} \\
\hat{\delta}\end{array}$ & $\frac{\hat{i}}{\hat{i}}$ & 今े & î̀ & $\stackrel{\hat{\imath}}{\stackrel{\rho}{\rho}}$ & $\stackrel{\hat{I}}{=}$ & $\stackrel{\vec{I}}{\mathrm{I}}$ & $\begin{array}{l}\stackrel{\infty}{1} \\
\frac{1}{0}\end{array}$ & 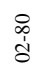 & $\begin{array}{l}\stackrel{p}{ } \\
\stackrel{0}{0}\end{array}$ & $\begin{array}{l}\stackrel{8}{0} \\
\text { +1 }\end{array}$ & $\begin{array}{l}0 \\
\phi \\
0 \\
0\end{array}$ & $\begin{array}{l}\otimes \\
0 \\
\dot{b}\end{array}$ & $\begin{array}{l}\stackrel{0}{\$} \\
\stackrel{0}{0}\end{array}$ & $\begin{array}{l}\otimes \\
\infty \\
\infty \\
0\end{array}$ & $\begin{array}{l}\stackrel{0}{0} \\
\text { ò }\end{array}$ & 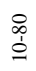 & $\stackrel{\otimes}{\stackrel{\infty}{=}}$ & 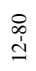 & $\begin{array}{l}\overrightarrow{\underline{p}} \\
\overrightarrow{0}\end{array}$ & $\begin{array}{l}\overrightarrow{\alpha_{0}} \\
\stackrel{d}{\delta}\end{array}$ & $\begin{array}{l}\vec{\infty} \\
\dot{\delta}\end{array}$ & $\begin{array}{l}\vec{\alpha} \\
\dot{0}\end{array}$ & $\begin{array}{l}\vec{\alpha} \\
\dot{b} \\
\delta\end{array}$ & $\begin{array}{l}\bar{\alpha} \\
\dot{b}\end{array}$ & $\begin{array}{l}\overline{p_{0}} \\
\vdots\end{array}$ & $\begin{array}{l}\vec{\alpha} \\
\dot{0}\end{array}$ & $\begin{array}{l}\vec{\alpha} \\
\vdots \\
\Delta\end{array}$ & $\begin{array}{l}\bar{\alpha} \\
\stackrel{0}{0}\end{array}$ & $\stackrel{\bar{\infty}}{=}$ & $\begin{array}{l}\vec{\alpha} \\
\dot{I}\end{array}$ & $\frac{\widetilde{O}}{\stackrel{1}{\sigma}}$ & 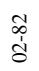 & $\begin{array}{l}\tilde{D} \\
\infty \\
\tilde{\sigma}\end{array}$ & 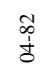 & $\begin{array}{l}\tilde{0} \\
0 \\
1 \\
0\end{array}$ \\
\hline & 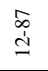 & $\begin{array}{l}\infty \\
\stackrel{\infty}{0} \\
\stackrel{1}{0}\end{array}$ & $\begin{array}{l}\infty \\
\infty \\
\delta \\
\delta\end{array}$ & $\begin{array}{l}\infty \\
\infty \\
0 \\
c \\
c\end{array}$ & $\begin{array}{l}\infty \\
\infty \\
\dot{0}\end{array}$ & $\begin{array}{l}\infty \\
\infty \\
0 \\
d \\
d\end{array}$ & $\begin{array}{l}\infty \\
\infty \\
\dot{0} \\
\delta\end{array}$ & $\begin{array}{l}\infty \\
0 \\
\vdots \\
\vdots \\
0\end{array}$ & $\begin{array}{l}\infty \\
\infty \\
\infty \\
\infty\end{array}$ & $\begin{array}{l}\infty \\
0 \\
8 \\
8\end{array}$ & $\begin{array}{l}\infty \\
\infty \\
\stackrel{\leftrightarrow}{\Theta}\end{array}$ & $\stackrel{\infty}{\stackrel{\infty}{\perp}}$ & 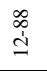 & 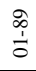 & $\begin{array}{l}\hat{d} \\
\text { dे }\end{array}$ & 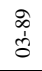 & $\begin{array}{l}a \\
\stackrel{0}{0} \\
\dot{0}\end{array}$ & $\begin{array}{l}\text { के } \\
\dot{0} \\
\dot{b}\end{array}$ & $\begin{array}{l}\text { के } \\
\text { ठे }\end{array}$ & 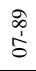 & $\begin{array}{l}\text { के } \\
\dot{1} \\
\dot{\delta}\end{array}$ & $\begin{array}{l}\text { के } \\
\text { ò }\end{array}$ & $\begin{array}{l}\stackrel{\infty}{o} \\
\stackrel{\rho}{\varrho}\end{array}$ & $\stackrel{\infty}{\stackrel{P}{=}}$ & 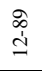 & $\frac{8}{\dot{1}}$ & 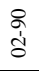 & के & $\frac{8}{\dot{1}}$ & $\begin{array}{l}8 \\
\text { d } \\
\text { r. }\end{array}$ & $\begin{array}{l}8 \\
8 \\
8\end{array}$ & 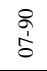 & $\begin{array}{l}8 \\
\stackrel{1}{0} \\
\stackrel{8}{0}\end{array}$ & $\begin{array}{l}8 \\
8 \\
8\end{array}$ & $\begin{array}{l}\text { \& } \\
\stackrel{1}{9}\end{array}$ & $\stackrel{8}{=}$ & $\stackrel{8}{\stackrel{8}{I}}$ & $\overrightarrow{\bar{i}}$ & $\begin{array}{l}\overline{1} \\
\dot{\delta}\end{array}$ \\
\hline$\frac{\mathrm{Ir}}{\mathrm{d}}$ & 2 & 2 & 2 & 2 & 2 & 2 & 2 & 2 & 2 & 2 & 2 & 2 & 2 & 2 & 12 & 2 & 2 & 10 & 2 & 2 & 2 & 2 & 2 & 2 & 2 & 2 & 2 & 2 & $\mathrm{~F}$ & 2 & 2 & 2 & 2 & 2 & $\mathrm{~F}$ & 2 & 2 & 2 & 2 \\
\hline 兑 & 8 & $\mathrm{~F}$ & $\mathrm{~F}$ & $\mathrm{~F}$ & $\mathrm{~F}$ & $\mathrm{~F}$ & $\mathrm{~F}$ & $\mathrm{~F}$ & 12 & $\mathrm{~F}$ & $\mathrm{~F}$ & $\mathrm{~F}$ & 13 & $\mathrm{~F}$ & $\mathrm{~F}$ & 12 & $\mathrm{~F}$ & $\mathrm{~F}$ & $\mathrm{~F}$ & 11 & 6 & $\mathrm{~F}$ & $\mathrm{~F}$ & $\mathrm{E}$ & 12 & $\mathrm{~F}$ & 12 & 7 & $\mathrm{~F}$ & 29 & $\mathrm{~F}$ & $\mathrm{~F}$ & $\mathrm{~F}$ & 63 & 62 & 13 & 32 & $\mathrm{~F}$ & $\mathrm{~F}$ \\
\hline 在 & 2 & $\mathrm{E}$ & $\mathrm{F}$ & $\mathrm{E}$ & C & $\mathrm{E}$ & $\mathrm{F}$ & $\mathrm{E}$ & 37 & F & $\mathrm{F}$ & $\mathrm{F}$ & 6 & 29 & 25 & $\mathrm{~F}$ & 13 & 21 & $\mathrm{E}$ & $\mathrm{E}$ & $\mathrm{F}$ & E & 34 & 4 & 42 & $\mathrm{~F}$ & 13 & $\mathrm{~F}$ & F & $\mathrm{F}$ & $\mathrm{F}$ & $\mathrm{F}$ & $\mathrm{F}$ & $\mathrm{F}$ & $\mathrm{F}$ & 6 & 28 & $\mathrm{~F}$ & 25 \\
\hline 㞋 & $\mathrm{F}$ & $\mathrm{F}$ & $\mathrm{F}$ & $\mathrm{F}$ & 19 & $\mathrm{~F}$ & $\mathrm{~F}$ & 21 & $\mathrm{~F}$ & 19 & $\mathrm{~F}$ & $\mathrm{~F}$ & $\mathrm{~F}$ & 7 & F & $\mathrm{F}$ & 7 & $\mathrm{~F}$ & $\mathrm{~F}$ & 7 & $\mathrm{~F}$ & F & 5 & $\mathrm{E}$ & $\mathrm{E}$ & $\mathrm{E}$ & E & E & 33 & $\mathrm{~F}$ & $\mathrm{~F}$ & $\mathrm{~F}$ & $\mathrm{~F}$ & 2 & 2 & F & $\mathrm{F}$ & $\mathrm{F}$ & F \\
\hline$\exists$ & $\mathrm{F}$ & 8 & 4 & 5 & 34 & 22 & 6 & 4 & 6 & 16 & $\mathrm{~F}$ & $\mathrm{C}$ & 11 & 13 & 22 & 77 & 11 & 27 & 21 & $\mathrm{~F}$ & $\mathrm{~F}$ & F & 4 & $\mathrm{~F}$ & 11 & $\mathrm{C}$ & $\mathrm{C}$ & C & C & $\mathrm{C}$ & C & $\mathrm{C}$ & $\mathrm{C}$ & $\mathrm{C}$ & $\mathrm{C}$ & 4 & E & 9 & C \\
\hline$\Leftrightarrow$ & E & $\mathrm{E}$ & E & $\mathrm{E}$ & E & E & $\mathrm{E}$ & E & $\mathrm{E}$ & E & $\mathrm{E}$ & $\mathrm{E}$ & $\mathrm{E}$ & E & $\mathrm{E}$ & $\mathrm{E}$ & $\mathrm{E}$ & $\mathrm{E}$ & $\mathrm{E}$ & E & $\mathrm{E}$ & E & $\mathrm{E}$ & $\mathrm{C}$ & $\mathrm{C}$ & C & $\mathrm{E}$ & 2 & 10 & $\mathrm{C}$ & C & $\mathrm{C}$ & $\mathrm{C}$ & $\mathrm{C}$ & $\mathrm{C}$ & E & $\mathrm{E}$ & E & E \\
\hline 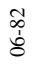 & $\begin{array}{l}\stackrel{⿰}{0} \\
\stackrel{1}{0}\end{array}$ & $\begin{array}{l}\text { Oे } \\
0 \\
0 \\
0\end{array}$ & $\begin{array}{l}\text { o } \\
\text { ô }\end{array}$ & 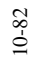 & $\stackrel{\stackrel{\infty}{\stackrel{P}{I}}}{=}$ & 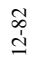 & $\stackrel{\infty}{\stackrel{\rho}{0}}$ & 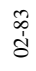 & $\begin{array}{l}\infty \\
\infty \\
\infty \\
\infty\end{array}$ & $\begin{array}{l}\mathscr{\infty} \\
\dot{0} \\
\dot{0}\end{array}$ & $\begin{array}{l}\text { Oे } \\
\dot{1} \\
\ddot{b}\end{array}$ & $\begin{array}{l}\text { Oో } \\
\dot{0} \\
\delta\end{array}$ & 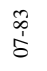 & $\begin{array}{l}\mathscr{\infty} \\
0 \\
0 \\
0\end{array}$ & $\begin{array}{l}\hat{\alpha} \\
\hat{d}\end{array}$ & $\begin{array}{l}\infty \\
\stackrel{0}{0} \\
\stackrel{1}{O}\end{array}$ & $\stackrel{\infty}{\stackrel{\infty}{\perp}}$ & $\begin{array}{l}\mathscr{O} \\
\stackrel{\bigcup}{\unlhd} \\
\end{array}$ & $\begin{array}{l}\underset{+}{+} \\
\stackrel{+}{0}\end{array}$ & $\begin{array}{l}\text { t. } \\
\text { 广े }\end{array}$ & 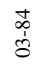 & $\begin{array}{l}+ \\
+ \\
+ \\
\dot{0}\end{array}$ & 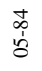 & $\begin{array}{l}+ \\
\dot{0} \\
\dot{8}\end{array}$ & $\begin{array}{l}\text { से } \\
\vdots \\
\vdots \\
0\end{array}$ & $\begin{array}{l}\text { t. } \\
\text { d } \\
\text { o }\end{array}$ & $\begin{array}{l}\text { t. } \\
\vdots \\
\text { ò }\end{array}$ & $\begin{array}{l}\text { to } \\
\text { 它 }\end{array}$ & $\begin{array}{l}\stackrel{+}{\stackrel{+}{I}} \\
=\end{array}$ & $\begin{array}{l}\stackrel{+}{0} \\
\stackrel{\Xi}{\beth}\end{array}$ & $\begin{array}{l}\stackrel{2}{\infty} \\
\stackrel{1}{0}\end{array}$ & $\begin{array}{l}\infty \\
0 \\
i \\
\tilde{\delta}\end{array}$ & $\begin{array}{l}\infty \\
\infty \\
\infty \\
\delta\end{array}$ & $\begin{array}{l}\infty \\
\infty \\
\dot{\delta}\end{array}$ & $\begin{array}{l}\infty \\
0 \\
\dot{0} \\
\ddot{b}\end{array}$ & 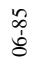 & $\begin{array}{l}\infty \\
\infty \\
\vdots \\
\vdots\end{array}$ & $\begin{array}{l}\infty \\
\infty \\
\infty \\
\infty\end{array}$ & $\begin{array}{l}1 \\
0 \\
0 \\
0 \\
8\end{array}$ \\
\hline बे & $\begin{array}{l}\bar{a} \\
\dot{d}\end{array}$ & वे & $\begin{array}{l}\overrightarrow{\hat{d}} \\
\text { bे }\end{array}$ & $\begin{array}{l}\bar{a} \\
\vdots\end{array}$ & $\begin{array}{l}\overline{a^{\prime}} \\
\dot{d}\end{array}$ & $\begin{array}{l}\bar{a} \\
\text { dे }\end{array}$ & बे & $\vec{i}$ & $\overrightarrow{\bar{d}}$ & $\frac{\tilde{i}}{0}$ & ふे & ๙े & 㑏 & $\begin{array}{l}\tilde{\gamma} \\
\text { dे }\end{array}$ & ठे & $\frac{\widetilde{1}}{\grave{\delta}}$ & $\stackrel{\widetilde{\alpha}}{\stackrel{\partial}{o}}$ & ลิ & مิ & $\stackrel{\widetilde{a}}{=}$ & $\stackrel{\widetilde{\Lambda}}{\check{I}}$ & $\frac{m}{0}$ & ஷิ̀ & ๙े & $\stackrel{\hat{q}}{\dot{d}}$ & के & ڤิे & $\begin{array}{l}\hat{a} \\
\vdots \\
\vdots\end{array}$ & $\begin{array}{l}\text { aे } \\
\dot{d}\end{array}$ & ầ & $\hat{\hat{\theta}}$ & $\stackrel{\curvearrowright}{\stackrel{\rho}{=}}$ & $\stackrel{\check{I}}{\underline{I}}$ & $\frac{a}{0}$ & ث্ণ & ते & $\frac{d}{d}$ & $\begin{array}{l}\text { tे } \\
\text { bे }\end{array}$ & के \\
\hline $\mathrm{F}$ & 2 & $\mathrm{~F}$ & 2 & 2 & $\mathrm{~F}$ & $\mathrm{~F}$ & 2 & $\mathrm{~F}$ & $\mathrm{~F}$ & 2 & $\mathrm{~F}$ & $\mathrm{~F}$ & $\mathrm{~F}$ & $\mathrm{~F}$ & $\mathrm{~F}$ & $\mathrm{~F}$ & $\mathrm{~F}$ & $\mathrm{~F}$ & $\mathrm{~F}$ & $\mathrm{~F}$ & $\mathrm{~F}$ & $\mathrm{~F}$ & $\mathrm{~F}$ & $\mathrm{~F}$ & $\mathrm{~F}$ & $\mathrm{~F}$ & $\mathrm{~F}$ & $\mathrm{~F}$ & $\mathrm{~F}$ & $\mathrm{E}$ & $\mathrm{E}$ & 12 & 12 & $\mathrm{~F}$ & $\mathrm{E}$ & 19 & 9 & $\mathrm{~F}$ & 9 \\
\hline F & $\mathrm{F}$ & $\mathrm{F}$ & $\mathrm{F}$ & $\mathrm{F}$ & 2 & 2 & 2 & 8 & 2 & E & $\mathrm{E}$ & 6 & $\mathrm{~F}$ & 2 & 2 & 2 & 2 & $\mathrm{~F}$ & 2 & 2 & $\mathrm{~F}$ & $\mathrm{~F}$ & E & $\mathrm{F}$ & $\mathrm{F}$ & 4 & 9 & $\mathrm{~F}$ & E & $\mathrm{F}$ & 2 & 5 & 21 & 20 & $\mathrm{~F}$ & $\mathrm{~F}$ & 18 & F & 56 \\
\hline E & $\mathrm{F}$ & $\mathrm{F}$ & $\mathrm{F}$ & 2 & 18 & 2 & $\mathrm{~F}$ & $\mathrm{~F}$ & $\mathrm{~F}$ & F & 15 & $\mathrm{~F}$ & 26 & 28 & 16 & 12 & 12 & $\mathrm{~F}$ & 13 & 27 & $\mathrm{~F}$ & 29 & $\mathrm{~F}$ & $\mathrm{~F}$ & $\mathrm{~F}$ & 55 & 11 & $\mathrm{~F}$ & 26 & 263 & E & 17 & 573 & 414 & 30 & $\mathrm{~F}$ & 176 & 163 & 39 \\
\hline F & 26 & 78 & 32 & 32 & $\mathrm{~F}$ & 26 & 6 & 17 & 102 & C & 2 & 2 & E & E & $\mathrm{E}$ & $\mathrm{E}$ & 8 & 2 & 2 & $\mathrm{~F}$ & 3 & $\mathrm{~F}$ & $\mathrm{E}$ & $\mathrm{E}$ & $\mathrm{F}$ & $\mathrm{F}$ & 20 & 64 & 23 & $\mathrm{E}$ & 51 & E & $\mathrm{E}$ & E & $\mathrm{E}$ & E & 11 & F & 40 \\
\hline C & $\mathrm{C}$ & C & C & C & C & C & $\mathrm{C}$ & C & $\mathrm{C}$ & C & $\mathrm{C}$ & $\mathrm{C}$ & $\mathrm{F}$ & 9 & 42 & $\mathrm{C}$ & 6 & $\mathrm{C}$ & $\mathrm{E}$ & E & $\mathrm{E}$ & E & $\mathrm{E}$ & $\mathrm{E}$ & E & E & E & E & E & $\mathrm{E}$ & E & $\mathrm{E}$ & 12 & $\mathrm{~F}$ & 22 & $\mathrm{~F}$ & 8 & 60 & 4 \\
\hline E & $\mathrm{E}$ & E & C & C & C & 18 & 10 & $\mathrm{~F}$ & 13 & $\mathrm{~F}$ & $\mathrm{~F}$ & $\mathrm{~F}$ & $\mathrm{~F}$ & $\mathrm{~F}$ & 14 & $\mathrm{~F}$ & $\mathrm{~F}$ & $\mathrm{C}$ & $\mathrm{F}$ & E & $\mathrm{C}$ & 2 & $\mathrm{~F}$ & $\mathrm{~F}$ & $\mathrm{~F}$ & $\mathrm{~F}$ & E & E & C & $\mathrm{C}$ & 51 & 141 & 34 & 24 & 7 & 4 & $\mathrm{~F}$ & 62 & 29 \\
\hline 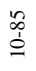 & $\stackrel{\infty}{\stackrel{\infty}{=}}$ & 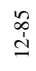 & $\begin{array}{l}\stackrel{0}{0} \\
\stackrel{0}{0}\end{array}$ & $\begin{array}{l}\stackrel{0}{ } \\
\stackrel{1}{\delta} \\
\text { ปे }\end{array}$ & $\begin{array}{l}\stackrel{0}{ } \\
\text { dे }\end{array}$ & 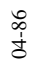 & 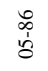 & $\begin{array}{l}\text { ० } \\
\text { bे } \\
\text { bे }\end{array}$ & $\begin{array}{l}0 \\
\$ \\
\vdots \\
0\end{array}$ & $\begin{array}{l}\stackrel{0}{\infty} \\
\dot{0} \\
\dot{0}\end{array}$ & $\begin{array}{l}\infty \\
ஷ \\
o\end{array}$ & $\begin{array}{l}\circ \\
\stackrel{0}{0} \\
\stackrel{1}{0}\end{array}$ & $\begin{array}{l}\stackrel{\infty}{\stackrel{p}{=}} \\
\stackrel{1}{=}\end{array}$ & $\begin{array}{l}\stackrel{0}{ } \\
\stackrel{1}{ป}\end{array}$ & $\stackrel{\bar{o}}{\frac{1}{\sigma}}$ & $\begin{array}{l}\hat{s} \\
\hat{d} \\
\hat{d}\end{array}$ & $\begin{array}{l}\hat{\infty} \\
\text { bे }\end{array}$ & $\begin{array}{l}\hat{\infty} \\
\dot{0} \\
\dot{0}\end{array}$ & $\begin{array}{l}\text { o. } \\
\text { r. }\end{array}$ & $\begin{array}{l}\text { के } \\
\text { bे }\end{array}$ & $\begin{array}{l}\hat{\infty} \\
\vdots \\
\vdots \\
0\end{array}$ & $\begin{array}{l}\infty \\
\infty \\
\infty \\
\infty\end{array}$ & $\begin{array}{l}\hat{\infty} \\
\text { ò }\end{array}$ & $\begin{array}{l}\infty \\
\dot{\infty} \\
\stackrel{\rho}{\rho}\end{array}$ & $\stackrel{\infty}{\stackrel{\infty}{=}}$ & $\begin{array}{l}\hat{o} \\
\stackrel{d}{\unlhd}\end{array}$ & 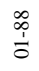 & \begin{tabular}{l}
$\infty$ \\
$\infty$ \\
\multirow{d}{\delta}{}
\end{tabular} & $\begin{array}{l}\infty \\
\infty \\
\infty \\
\tilde{b}\end{array}$ & $\begin{array}{l}\infty \\
\infty \\
0 \\
d\end{array}$ & $\begin{array}{l}\infty \\
0 \\
0 \\
b\end{array}$ & $\begin{array}{l}\infty \\
\infty \\
0 \\
\delta \\
\delta\end{array}$ & $\begin{array}{l}\infty \\
\infty \\
\vdots \\
\vdots \\
0\end{array}$ & $\begin{array}{l}\infty \\
\infty \\
\infty \\
\infty \\
0\end{array}$ & $\begin{array}{l}\infty \\
\infty \\
o \\
o\end{array}$ & 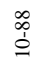 & 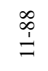 & $\begin{array}{l}\infty \\
\stackrel{0}{I} \\
\stackrel{I}{I}\end{array}$ & $\begin{array}{l}\stackrel{\alpha}{\phi} \\
\stackrel{1}{\sigma}\end{array}$ \\
\hline $\begin{array}{l}\text { t } \\
\text { 今े }\end{array}$ & $\begin{array}{l}\text { t } \\
\dot{0} \\
\dot{0}\end{array}$ & $\begin{array}{l}\text { t } \\
\text { gे }\end{array}$ & $\begin{array}{l}\text { ta } \\
\stackrel{d}{\varrho}\end{array}$ & $\stackrel{+}{\stackrel{+}{I}}$ & 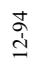 & $\frac{a}{a}$ & 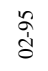 & $\begin{array}{l}\text { aे } \\
\text { dे }\end{array}$ & $\begin{array}{l}a \\
\dot{a} \\
\dot{d}\end{array}$ & 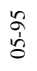 & $\begin{array}{l}\text { ฉे } \\
\text { \&े }\end{array}$ & 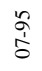 & $\begin{array}{l}\stackrel{n}{a} \\
\stackrel{0}{o}\end{array}$ & $\begin{array}{l}\text { aे } \\
\text { ò }\end{array}$ & 哭 & $\stackrel{a}{a}$ & $\begin{array}{l}\stackrel{a}{a} \\
\stackrel{\jmath}{d}\end{array}$ & $\frac{8}{1}$ & $\begin{array}{l}\text { \& } \\
\text { తి }\end{array}$ & $\begin{array}{l}\text { के } \\
\text { வे }\end{array}$ & $\begin{array}{l}\stackrel{8}{0} \\
\text { ț }\end{array}$ & $\begin{array}{l}\text { वे } \\
\text { ì }\end{array}$ & $\begin{array}{l}\text { \&े } \\
\text { ठे }\end{array}$ & $\begin{array}{l}\stackrel{0}{1} \\
\vdots\end{array}$ & $\begin{array}{l}\stackrel{0}{\circ} \\
\stackrel{0}{0}\end{array}$ & $\begin{array}{l}\text { \& } \\
\text { ô }\end{array}$ & 官 & $\stackrel{\circ}{\stackrel{\circ}{=}}$ & $\begin{array}{l}\stackrel{8}{d} \\
\stackrel{d}{d}\end{array}$ & $\frac{a}{\grave{a}}$ & $\begin{array}{l}\text { बें } \\
\text { dे }\end{array}$ & बे & $\begin{array}{l}\hat{a} \\
\hat{d}\end{array}$ & $\begin{array}{l}\hat{a} \\
\text { s. }\end{array}$ & $\begin{array}{l}\hat{a} \\
\text { bे }\end{array}$ & $\begin{array}{l}\text { aे } \\
\text { ⿳亠口冋 }\end{array}$ & $\begin{array}{l}\hat{a} \\
\dot{a} \\
\dot{d}\end{array}$ & $\begin{array}{l}\hat{a} \\
\text { d̀ }\end{array}$ & $\hat{a}$ \\
\hline F & 12 & 7 & $\mathrm{~F}$ & $\mathrm{~F}$ & F & $\mathrm{F}$ & $\mathrm{F}$ & $\mathrm{F}$ & $\mathrm{F}$ & F & $\mathrm{F}$ & $\mathrm{F}$ & 9 & $\mathrm{~F}$ & $\mathrm{~F}$ & $\mathrm{~F}$ & $\mathrm{~F}$ & $\mathrm{~F}$ & $\mathrm{~F}$ & $\mathrm{~F}$ & $\mathrm{~F}$ & $\mathrm{~F}$ & $\mathrm{~F}$ & $\mathrm{~F}$ & $\mathrm{~F}$ & $\mathrm{~F}$ & $\mathrm{~F}$ & $\mathrm{~F}$ & $\mathrm{~F}$ & $\mathrm{~F}$ & $\mathrm{~F}$ & $\mathrm{~F}$ & $\mathrm{~F}$ & F & $\mathrm{F}$ & 7 & F & F & $\mathrm{F}$ \\
\hline 3 & 10 & $\mathrm{~F}$ & $\mathrm{~F}$ & $\mathrm{~F}$ & F & $\mathrm{F}$ & $\mathrm{F}$ & $\mathrm{F}$ & $\mathrm{F}$ & F & $\mathrm{F}$ & $\mathrm{F}$ & $\mathrm{F}$ & 11 & 11 & $\mathrm{~F}$ & $\mathrm{~F}$ & 19 & $\mathrm{~F}$ & $\mathrm{~F}$ & $\mathrm{~F}$ & $\mathrm{~F}$ & $\mathrm{~F}$ & $\mathrm{~F}$ & $\mathrm{~F}$ & $\mathrm{~F}$ & $\mathrm{~F}$ & $\mathrm{~F}$ & $\mathrm{~F}$ & $\mathrm{~F}$ & $\mathrm{~F}$ & $\mathrm{~F}$ & 13 & $\mathrm{~F}$ & $\mathrm{~F}$ & $\mathrm{~F}$ & $\mathrm{~F}$ & F & $\mathrm{F}$ \\
\hline 51 & $\mathrm{~F}$ & 37 & 10 & 75 & $\mathrm{~F}$ & $\mathrm{~F}$ & 135 & 79 & $\mathrm{~F}$ & F & 21 & $\mathrm{~F}$ & $\mathrm{~F}$ & 14 & 216 & 55 & 20 & $\mathrm{~F}$ & 23 & $\mathrm{~F}$ & 8 & $\mathrm{~F}$ & $\mathrm{~F}$ & $\mathrm{~F}$ & $\mathrm{~F}$ & $\mathrm{~F}$ & 27 & $\mathrm{~F}$ & 16 & 9 & $\mathrm{~F}$ & F & 8 & 4 & $\mathrm{~F}$ & 8 & 8 & F & 14 \\
\hline F & C & C & $\mathrm{E}$ & C & 14 & $\mathrm{~F}$ & $\mathrm{~F}$ & $\mathrm{~F}$ & $\mathrm{E}$ & E & E & $\mathrm{E}$ & E & E & 23 & $\mathrm{~F}$ & $\mathrm{E}$ & 23 & $\mathrm{~F}$ & E & $\mathrm{E}$ & E & E & $\mathrm{E}$ & E & E & E & E & E & $\mathrm{E}$ & 8 & 2 & 2 & F & 26 & 10 & 12 & 17 & E \\
\hline $\mathrm{F}$ & 14 & $\mathrm{~F}$ & E & E & E & E & $\mathrm{E}$ & E & $\mathrm{E}$ & E & E & C & C & C & $\mathrm{E}$ & $\mathrm{E}$ & $\mathrm{E}$ & $\mathrm{E}$ & E & E & $\mathrm{E}$ & E & E & $\mathrm{F}$ & $\mathrm{F}$ & $\mathrm{F}$ & $\mathrm{F}$ & $\mathrm{F}$ & $\mathrm{F}$ & F & $\mathrm{F}$ & F & $\mathrm{F}$ & F & $\mathrm{F}$ & $\mathrm{F}$ & $\mathrm{F}$ & F & $\mathrm{F}$ \\
\hline $\mathrm{F}$ & 7 & $\mathrm{~F}$ & $\mathrm{~F}$ & F & $\mathrm{F}$ & $\mathrm{F}$ & F & $\mathrm{F}$ & 6 & F & C & C & C & E & 269 & $\mathrm{~F}$ & $\mathrm{~F}$ & $\mathrm{C}$ & C & C & $\mathrm{E}$ & E & $\mathrm{E}$ & E & $\mathrm{F}$ & $\mathrm{F}$ & $\mathrm{F}$ & $\mathrm{F}$ & $\mathrm{F}$ & E & 44 & $\mathrm{C}$ & $\mathrm{C}$ & E & $\mathrm{E}$ & E & $\mathrm{C}$ & $\mathrm{C}$ & C \\
\hline
\end{tabular}

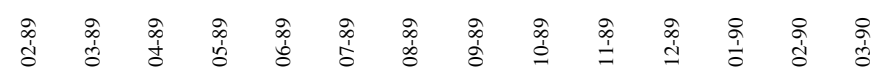

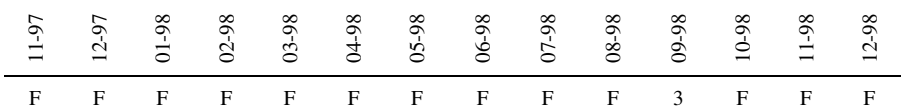


Table 1: Estimation Results (no switching)

\begin{tabular}{|c|c|c|c|c|c|c|c|c|}
\hline & $\mathrm{Be}$ & De & $\mathrm{Fr}$ & $\mathrm{Nl}$ & It & Ir & Po & Sp \\
\hline$\psi_{1, \mathrm{k}}$ & $\begin{array}{c}0.729 * * * \\
(0280)\end{array}$ & $\begin{array}{c}0.503 \\
(0.426)\end{array}$ & $\begin{array}{c}-1.049 * * * \\
(0336)\end{array}$ & $\begin{array}{c}-0.371 \\
(0.419)\end{array}$ & $\begin{array}{c}-1.094 * * * \\
(0234)\end{array}$ & $\begin{array}{l}-0.031 \\
(0.142)\end{array}$ & $\begin{array}{l}0.460 * \\
(0.251)\end{array}$ & $\begin{array}{c}1.390^{* * * *} \\
(0495)\end{array}$ \\
\hline$\psi_{2, \mathrm{k}}$ & $\begin{array}{c}-0.956 * * * \\
(0.137)\end{array}$ & $\begin{array}{l}-0.276 \\
(0.192)\end{array}$ & $\begin{array}{l}-0.064 \\
(0.125)\end{array}$ & $\begin{array}{l}-0.950 \\
(0.807)\end{array}$ & $\begin{array}{c}0.397 \\
(0.285)\end{array}$ & $\begin{array}{c}-0.379 * * * \\
(0.086)\end{array}$ & $\begin{array}{c}-1.661 * * \\
(0.650)\end{array}$ & $\begin{array}{c}-4.592 * * * \\
(1.012)\end{array}$ \\
\hline$\psi_{1,1}$ & $\begin{array}{c}-1.321 * * * \\
(0.287)\end{array}$ & $\begin{array}{l}-0.569 \\
(0.423)\end{array}$ & $\begin{array}{l}0.672 * \\
(0.333)\end{array}$ & $\begin{array}{c}0.013 \\
(0.312)\end{array}$ & $\begin{array}{c}0.928 * * * \\
(0.194)\end{array}$ & $\begin{array}{l}-0.274 \\
(0.206)\end{array}$ & $\begin{array}{c}-1.661 * * \\
(0.650)\end{array}$ & $\begin{array}{c}0.171 \\
(0.362)\end{array}$ \\
\hline$\psi_{2,1}$ & $\begin{array}{c}0.594 * * * \\
(0.168)\end{array}$ & $\begin{array}{c}-0.529 * * \\
(0.214)\end{array}$ & $\begin{array}{c}0.080 \\
(0.121)\end{array}$ & $\begin{array}{c}0.531 \\
(0.524)\end{array}$ & $\begin{array}{c}-0.285^{* *} \\
(0.136)\end{array}$ & $\begin{array}{c}0.072 \\
(0.075)\end{array}$ & $\begin{array}{c}1.753 * * * \\
(0.534)\end{array}$ & $\begin{array}{c}0.659 \\
(0.553)\end{array}$ \\
\hline$\lambda_{1,1}$ & $\begin{array}{c}-0.033 \\
(0.046)\end{array}$ & $\begin{array}{c}-0.402 \\
(0.342)\end{array}$ & $\begin{array}{l}-0.211 \\
(0.514)\end{array}$ & $\begin{array}{l}-0.123 \\
(2.025)\end{array}$ & $\begin{array}{c}0.003 * * * \\
(0.001)\end{array}$ & $\begin{array}{c}1.799 \\
(3.761)\end{array}$ & $\begin{array}{c}0.045^{* *} \\
(0.020)\end{array}$ & $\begin{array}{l}-0.012 \\
(0.009)\end{array}$ \\
\hline$\lambda_{1,2}$ & $\begin{array}{l}-0.030 \\
(0.046)\end{array}$ & $\begin{array}{l}-0.399 \\
(0.340)\end{array}$ & $\begin{array}{l}-0.211 \\
(0.514)\end{array}$ & $\begin{array}{l}-0.123 \\
(2.014)\end{array}$ & $\begin{array}{c}0.003 * * * \\
(0.001)\end{array}$ & $\begin{array}{c}1.863 \\
(3.768)\end{array}$ & $\begin{array}{c}0.050 * * \\
(0.019)\end{array}$ & $\begin{array}{c}-0.011 \\
(0.009)\end{array}$ \\
\hline$\lambda_{2,1}$ & $\begin{array}{l}-0.033 \\
(0.084)\end{array}$ & $\begin{array}{c}0.315 \\
(0.659)\end{array}$ & $\begin{array}{c}0.606 \\
(0.419)\end{array}$ & $\begin{array}{c}-14.732 \\
(9.522)\end{array}$ & $\begin{array}{c}-0.003 * * * \\
(0.001)\end{array}$ & $\begin{array}{l}-1.862 \\
(9.697)\end{array}$ & $\begin{array}{c}-0.598 * * * \\
(0.090)\end{array}$ & $\begin{array}{c}-0.050 * * \\
(0.021)\end{array}$ \\
\hline$\lambda_{2,1}$ & $\begin{array}{l}-0.033 \\
(0.084)\end{array}$ & $\begin{array}{c}0.314 \\
(0.660)\end{array}$ & $\begin{array}{c}0.607 \\
(0.420)\end{array}$ & $\begin{array}{c}-14.731 \\
(9.523)\end{array}$ & $\begin{array}{c}-0.003 * * * * \\
(0.001)\end{array}$ & $\begin{array}{l}-1.886 \\
(9.708)\end{array}$ & $\begin{array}{c}-0.598 * * * \\
(0.090)\end{array}$ & $\begin{array}{c}-0.049 * * \\
(0.020)\end{array}$ \\
\hline$\alpha_{1, \mathrm{k}}$ & $\begin{array}{c}-0.748 * * * \\
(0.259)\end{array}$ & $\begin{array}{l}0.477 * \\
(0.269)\end{array}$ & $\begin{array}{c}0.333 \\
(0.325)\end{array}$ & $\begin{array}{c}-0.690 * * \\
(0.306)\end{array}$ & $\begin{array}{c}-0.686 * * * \\
(0.258)\end{array}$ & $\begin{array}{c}0.431 \\
(0.280)\end{array}$ & $\begin{array}{l}-0.218 \\
(0.714)\end{array}$ & $\begin{array}{c}-0.684 * * \\
(0.324)\end{array}$ \\
\hline$\alpha_{2, \mathrm{k}}$ & $\begin{array}{l}0.426^{*} \\
(0.236)\end{array}$ & $\begin{array}{c}-1.208 * * * \\
(0.320)\end{array}$ & $\begin{array}{l}-0.036 \\
(0.164)\end{array}$ & $\begin{array}{c}2.235 * * * \\
(0.670)\end{array}$ & $\begin{array}{c}0.410 * * \\
(0.198)\end{array}$ & $\begin{array}{c}-0.711 * * * \\
(0.203)\end{array}$ & $\begin{array}{c}17.227 * * * \\
(2.508)\end{array}$ & $\begin{array}{l}1.483 * * \\
(0.567)\end{array}$ \\
\hline$\alpha_{1,1}$ & $\begin{array}{c}0.308 \\
(0.226)\end{array}$ & $\begin{array}{l}-0.908 * \\
(0.467)\end{array}$ & $\begin{array}{l}-0.293 \\
(0.330)\end{array}$ & $\begin{array}{l}-0.029 \\
(0.295)\end{array}$ & $\begin{array}{l}-0.155 \\
(0.277)\end{array}$ & $\begin{array}{c}-0.904 * * * \\
(0.319)\end{array}$ & $\begin{array}{c}0.392 \\
(0.295)\end{array}$ & $\begin{array}{c}-0.452 \\
(0.350)\end{array}$ \\
\hline$\alpha_{2,1}$ & $\begin{array}{c}0.026 \\
(0.142)\end{array}$ & $\begin{array}{c}0.180 \\
(0.359)\end{array}$ & $\begin{array}{c}0.331 * * \\
(0.166)\end{array}$ & $\begin{array}{c}0.132 \\
(0.676)\end{array}$ & $\begin{array}{c}-0.252^{* * *} \\
(0.116)\end{array}$ & $\begin{array}{c}0.214 \\
(0.162)\end{array}$ & $\begin{array}{l}-1.813 \\
(1.238)\end{array}$ & $\begin{array}{c}3.106^{* * * *} \\
(0.668)\end{array}$ \\
\hline$R^{2}$ & 0.477 & 0.320 & 0.335 & 0.273 & 0.282 & 0.314 & 0.824 & 0.535 \\
\hline
\end{tabular}

Notes: Table 1 presents the estimation results of the model formed by Equations (6), (13), (14) and (15). The $\psi$ 's represent the coefficients for fundamentalism; $\lambda$ for MA-chartism and $\alpha$ for AR-chartism. Subscripts 1 and 2 indicate the direct and position dependent effect, respectively; $k$ and $l$ represent the optimal lags (see the Appendix). Standard errors are given in parenthesis. ${ }^{*}, *$, and $* * *$ denote rejection at the 10,5 and $1 \%$ level, respectively. $R^{2}$ is the adjusted $\mathrm{r}$ squared. Be denotes Belgium; De Denmark; Fr France; Nl Netherlands; It Italy; Ir Ireland; Po Portugal and Sp Spain. 
Table 2: Estimation Results (with switching)

\begin{tabular}{|c|c|c|c|c|c|c|c|c|}
\hline & $\mathrm{Be}$ & De & $\mathrm{Fr}$ & $\mathrm{Nl}$ & It & Ir & Po & $\mathrm{Sp}$ \\
\hline$\psi_{l, k}$ & $\begin{array}{c}0.715^{* *} \\
(0.282)\end{array}$ & $\begin{array}{c}0.346 \\
(0.413)\end{array}$ & $\begin{array}{c}-0.372 * * \\
(0.173)\end{array}$ & $\begin{array}{l}-0.415 \\
(0.339)\end{array}$ & $\begin{array}{c}-1.002 * * * \\
(0.167)\end{array}$ & $\begin{array}{l}-0.062 \\
(0.132)\end{array}$ & $\begin{array}{c}0.441^{* * *} \\
(0.096)\end{array}$ & $\begin{array}{c}0.561 * * * \\
(0.203)\end{array}$ \\
\hline$\psi_{2, k}$ & $\begin{array}{c}-0.952 * * * \\
(0.138)\end{array}$ & $\begin{array}{c}-0.446 * * * \\
(0.160)\end{array}$ & $\begin{array}{c}-0.201 * * * \\
(0.061)\end{array}$ & $\begin{array}{l}-0.498 \\
(0.832)\end{array}$ & $\begin{array}{c}0.592 * * * \\
(0.111)\end{array}$ & $\begin{array}{c}-0.288 * * * \\
(0.081)\end{array}$ & $\begin{array}{c}-2.667 * * * * \\
(0.234)\end{array}$ & $\begin{array}{c}-1.551 * * * \\
(0.261)\end{array}$ \\
\hline$\psi_{1, l}$ & $\begin{array}{c}-1.302 * * * \\
(0.290)\end{array}$ & $\begin{array}{l}-0.608 \\
(0.418)\end{array}$ & $\begin{array}{c}0.341 * * \\
(0.160)\end{array}$ & $\begin{array}{l}-0.211 \\
(0.289)\end{array}$ & $\begin{array}{c}0.862 * * * \\
(0.155)\end{array}$ & $\begin{array}{l}-0.241 \\
(0.193)\end{array}$ & $\begin{array}{l}-0.120 \\
(0.102)\end{array}$ & $\begin{array}{c}0.103 \\
(0.261)\end{array}$ \\
\hline$\psi_{2, l}$ & $\begin{array}{c}0.591 * * * \\
(0.169)\end{array}$ & $\begin{array}{l}-0.011 \\
(0.220)\end{array}$ & $\begin{array}{c}0.162 * * * \\
(0.058)\end{array}$ & $\begin{array}{l}1.414 * * \\
(0.567)\end{array}$ & $\begin{array}{l}-0.227 * \\
(0.118)\end{array}$ & $\begin{array}{c}0.060 \\
(0.071)\end{array}$ & $\begin{array}{c}-1.030 * * * \\
(0.313)\end{array}$ & $\begin{array}{c}0.519 \\
(0.549)\end{array}$ \\
\hline$\lambda_{1,1}$ & $\begin{array}{l}-0.034 \\
(0.046)\end{array}$ & $\begin{array}{l}-0.254 \\
(0.349)\end{array}$ & $\begin{array}{c}0.009 \\
(0.122)\end{array}$ & $\begin{array}{c}-0.621 \\
(1.921)\end{array}$ & $\begin{array}{c}0.003 * * * \\
(0.001)\end{array}$ & $\begin{array}{c}4.415 \\
(3.797)\end{array}$ & $\begin{array}{c}0.026 * * * \\
(0.007)\end{array}$ & $\begin{array}{c}-0.024 * * * \\
(0.006)\end{array}$ \\
\hline$\lambda_{1,2}$ & $\begin{array}{l}-0.031 \\
(0.046)\end{array}$ & $\begin{array}{l}-0.254 \\
(0.348)\end{array}$ & $\begin{array}{c}0.009 \\
(0.123)\end{array}$ & $\begin{array}{l}-0.620 \\
(1.921)\end{array}$ & $\begin{array}{c}0.003 * * * \\
(0.001)\end{array}$ & $\begin{array}{c}4.468 \\
(3.803)\end{array}$ & $\begin{array}{c}0.026 * * * \\
(0.007)\end{array}$ & $\begin{array}{c}-0.023 * * * \\
(0.006)\end{array}$ \\
\hline$\lambda_{2,1}$ & $\begin{array}{l}-0.028 \\
(0.085)\end{array}$ & $\begin{array}{c}0.052 \\
(0.793)\end{array}$ & $\begin{array}{l}-0.044 \\
(0.427)\end{array}$ & $\begin{array}{l}-5.105 \\
(8.919)\end{array}$ & $\begin{array}{c}-0.003 * * * \\
(0.001)\end{array}$ & $\begin{array}{l}-8.413 \\
(9.687)\end{array}$ & $\begin{array}{c}-0.256 * * * \\
(0.051)\end{array}$ & $\begin{array}{c}0.028 * * \\
(0.012)\end{array}$ \\
\hline$\lambda_{2,1}$ & $\begin{array}{l}-0.028 \\
(0.085)\end{array}$ & $\begin{array}{c}0.054 \\
(0.794)\end{array}$ & $\begin{array}{l}-0.045 \\
(0.428)\end{array}$ & $\begin{array}{l}-5.113 \\
(8.919)\end{array}$ & $\begin{array}{c}-0.004 * * * \\
(0.001)\end{array}$ & $\begin{array}{l}-8.447 \\
(9.698)\end{array}$ & $\begin{array}{c}-0.256 * * * \\
(0.051)\end{array}$ & $\begin{array}{c}0.028 * * \\
(0.012)\end{array}$ \\
\hline$\alpha_{1, \mathrm{k}}$ & $\begin{array}{c}-0.734 * * * \\
(0.265)\end{array}$ & $\begin{array}{l}0.444^{*} \\
(0.265)\end{array}$ & $\begin{array}{c}-0.253^{* * * *} \\
(0.075)\end{array}$ & $\begin{array}{c}-0.604 * * * \\
(0.216)\end{array}$ & $\begin{array}{c}-0.478 * * \\
(0.223)\end{array}$ & $\begin{array}{c}0.271 \\
(0.267)\end{array}$ & $\begin{array}{c}0.710^{* * * *} \\
(0.118)\end{array}$ & $\begin{array}{c}-0.606^{* *} \\
(0.233)\end{array}$ \\
\hline$\alpha_{2, \mathrm{k}}$ & $\begin{array}{l}0.432^{*} \\
(0.236)\end{array}$ & $\begin{array}{c}-1.481 * * * \\
(0.429)\end{array}$ & $\begin{array}{c}0.096^{* *} \\
(0.038)\end{array}$ & $\begin{array}{c}1.905^{* * *} * \\
(0.483)\end{array}$ & $\begin{array}{c}0.508 * * * \\
(0.115)\end{array}$ & $\begin{array}{l}-0.275^{*} \\
(0.169)\end{array}$ & $\begin{array}{c}-1.579 * * * \\
(0.479)\end{array}$ & $\begin{array}{c}1.520 * * * \\
(0.355)\end{array}$ \\
\hline$\alpha_{1,1}$ & $\begin{array}{c}0.308 \\
(0.226)\end{array}$ & $\begin{array}{l}-0.278 \\
(0.414)\end{array}$ & $\begin{array}{c}-0.403 * * * \\
(0.118)\end{array}$ & $\begin{array}{c}-0.363^{* *} \\
(0.183)\end{array}$ & $\begin{array}{l}-0.003 \\
(0.230)\end{array}$ & $\begin{array}{c}-0.877 * * * \\
(0.306)\end{array}$ & $\begin{array}{c}0.246 \\
(0.193)\end{array}$ & $\begin{array}{l}-0.140 \\
(0.194)\end{array}$ \\
\hline$\alpha_{2,1}$ & $\begin{array}{c}0.029 \\
(0.142)\end{array}$ & $\begin{array}{l}-0.259 \\
(0.416)\end{array}$ & $\begin{array}{c}0.410 * * * \\
(0.059)\end{array}$ & $\begin{array}{c}0.358 \\
(0.483)\end{array}$ & $\begin{array}{c}-0.299 * * * \\
(0.101)\end{array}$ & $\begin{array}{c}0.205 \\
(0.158)\end{array}$ & $\begin{array}{c}3.785^{* * * *} \\
(1.168)\end{array}$ & $\begin{array}{c}1.648 * * * \\
(0.471)\end{array}$ \\
\hline$\gamma^{*}$ & $\begin{array}{c}2.92 \mathrm{E}-05 \\
(4.27 \mathrm{E}-05)\end{array}$ & $\begin{array}{c}0.009 \\
(0.006)\end{array}$ & $\begin{array}{l}-3.776 \\
(4.011)\end{array}$ & $\begin{array}{l}0.344 * * \\
(0.157)\end{array}$ & $\begin{array}{c}7.75 \mathrm{E}-05 * * * \\
(2.85 \mathrm{E}-05)\end{array}$ & $\begin{array}{c}0.027 \\
(0.019)\end{array}$ & $\begin{array}{c}0.147 \\
(0.237)\end{array}$ & $\begin{array}{c}0.004 \\
(0.002)\end{array}$ \\
\hline$R^{2}$ & 0.446 & 0.344 & 0.483 & 0.295 & 0.428 & 0.344 & 0.853 & 0.636 \\
\hline
\end{tabular}

Notes: Table 2 presents the estimation results of the model formed by Equations (6), (13), (14) and (15). The $\psi$ 's represent the coefficients for fundamentalism; $\lambda$ for MA-chartism and $\alpha$ for AR-chartism. $\gamma^{*}=\gamma / \mu$ represents the switching parameter. Subscripts 1 and 2 indicate the direct and position dependent effect, respectively; $k$ and $l$ represent the optimal lags (see the Appendix). Standard errors are given in parenthesis. *,**, and *** denote rejection at the 10,5 and $1 \%$ level, respectively. $R^{2}$ is the adjusted r-squared. Be denotes Belgium; De Denmark; Fr France; Nl Netherlands; It Italy; Ir Ireland; Po Portugal and Sp Spain. 
Table 3: Forecasting power

\begin{tabular}{|c|c|c|c|c|c|}
\hline & & 1 Month & 3 Months & 6 Months & 12 Months \\
\hline \multirow[t]{2}{*}{$\mathrm{Be}$} & MAE & 0.976 & $0.830 * *$ & $0.777 * * *$ & $0.799 * * *$ \\
\hline & MSE & $0.565 * * *$ & $0.419 * * *$ & $0.409 * * *$ & $0.596 * * *$ \\
\hline \multirow[t]{2}{*}{ Dk } & MAE & $0.917 * * *$ & $0.856 * * *$ & $0.275^{*} * *$ & $0.718 * * *$ \\
\hline & MSE & $0.675^{* * *}$ & $0.591 * * *$ & $0.544 * * *$ & $0.553 * * *$ \\
\hline \multirow[t]{2}{*}{$\mathrm{Fr}$} & MAE & 0.906 & $0.777 * * *$ & $0.747 * * *$ & $0.787 * * *$ \\
\hline & MSE & $0.557 * * *$ & $0.464 * * *$ & $0.516^{* * *}$ & $0.617 * * *$ \\
\hline \multirow[t]{2}{*}{$\mathrm{Nl}$} & MAE & $0.956 * * *$ & $0.859 * * *$ & $0.810 * * *$ & $0.868 * * *$ \\
\hline & MSE & $0.703 * * *$ & $0.477 * * *$ & $0.475^{* * *}$ & $0.663 * * *$ \\
\hline \multirow[t]{2}{*}{$\mathrm{Ir}$} & MAE & 0.939 & $0.850 * * *$ & $0.764 * * *$ & $0.756^{* * *}$ \\
\hline & MSE & $0.639 * * *$ & $0.581 * * *$ & $0.582 * * *$ & $0.586^{* * *}$ \\
\hline \multirow[t]{2}{*}{ It } & MAE & 0.994 & $0.897^{*}$ & 0.932 & 0.923 \\
\hline & MSE & $0.731 * *$ & $0.587 * *$ & 0.832 & $1.580 * *$ \\
\hline \multirow[t]{2}{*}{ Po } & MAE & $1.668 * * *$ & $1.652 * * *$ & $1.777 * * *$ & 1.022 \\
\hline & MSE & $4.375^{* * *}$ & $4.631 * * *$ & $5.131 * * *$ & $1.617 * * *$ \\
\hline \multirow[t]{2}{*}{$\mathrm{Sp}$} & MAE & $0.668 * * *$ & $0.832 * * *$ & 0.975 & 1.043 \\
\hline & MSE & $0.338 * * *$ & $0.575^{* * *} *$ & $0.821^{* *}$ & 0.885 \\
\hline
\end{tabular}

Notes: Table 3 presents the ratios between the forecast errors made by the model versus the random walk, i.e. a value larger (smaller) than one indicates a better forecasting performance for the random walk (model). $*, * *, * * *$ denotes rejection of the null hypothesis of no difference in forecasting performance at the 10,5 , and $1 \%$ level respectively by the DyboldMariano test statistic. MAE denotes Mean Absolute Error; MSE Mean Squared error. Be represents Belgium; De Denmark; Fr France; N1 Netherlands; It Italy; Ir Ireland; Po Portugal and Sp Spain. 
Figure 1: Weights
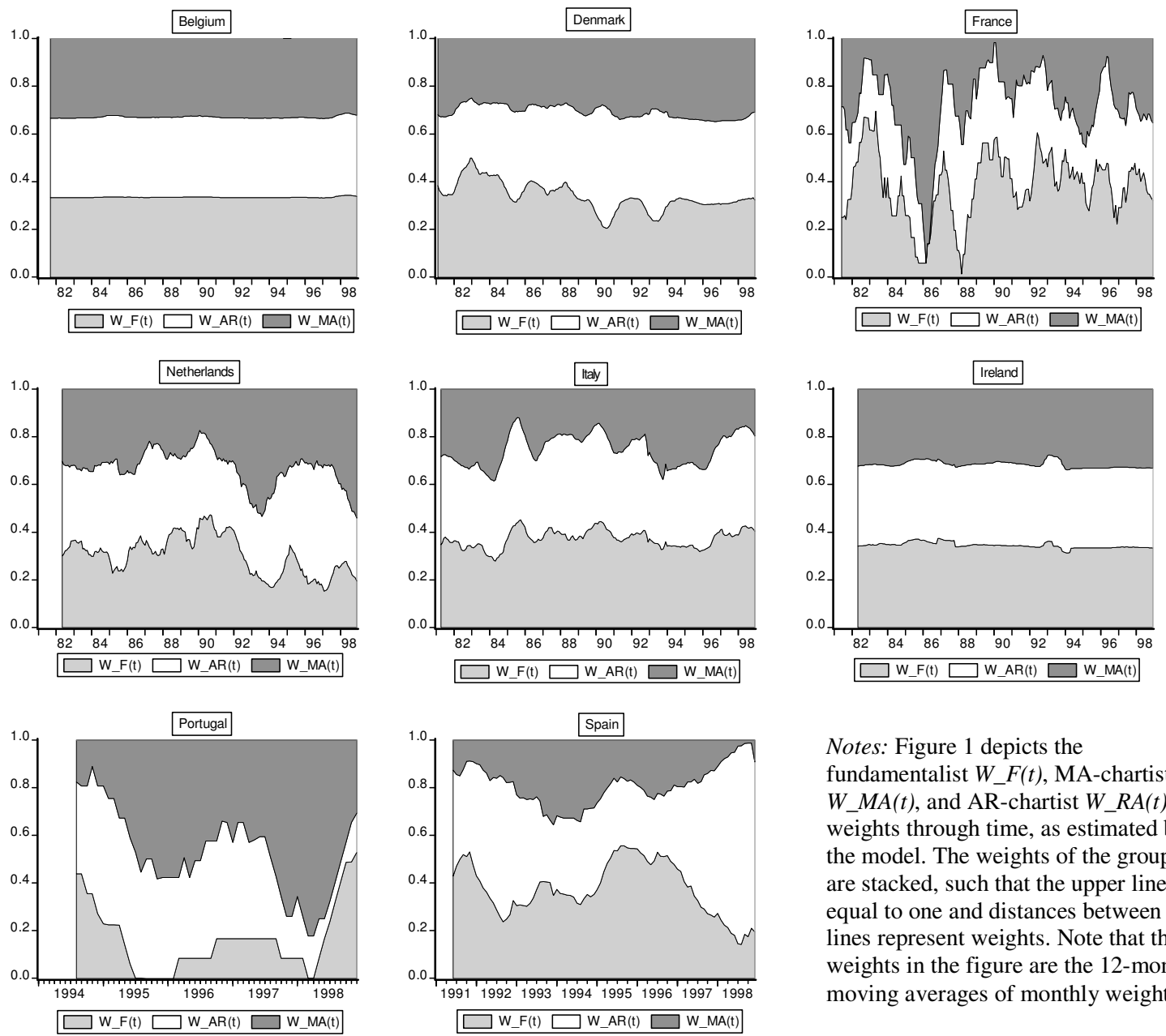

Notes: Figure 1 depicts the

fundamentalist $W_{-} F(t)$, MA-chartist $W \_M A(t)$, and AR-chartist $W \_R A(t)$ weights through time, as estimated by the model. The weights of the groups are stacked, such that the upper line is equal to one and distances between the lines represent weights. Note that the weights in the figure are the 12-month moving averages of monthly weights. 
Figure 2: Profit difference versus weight difference
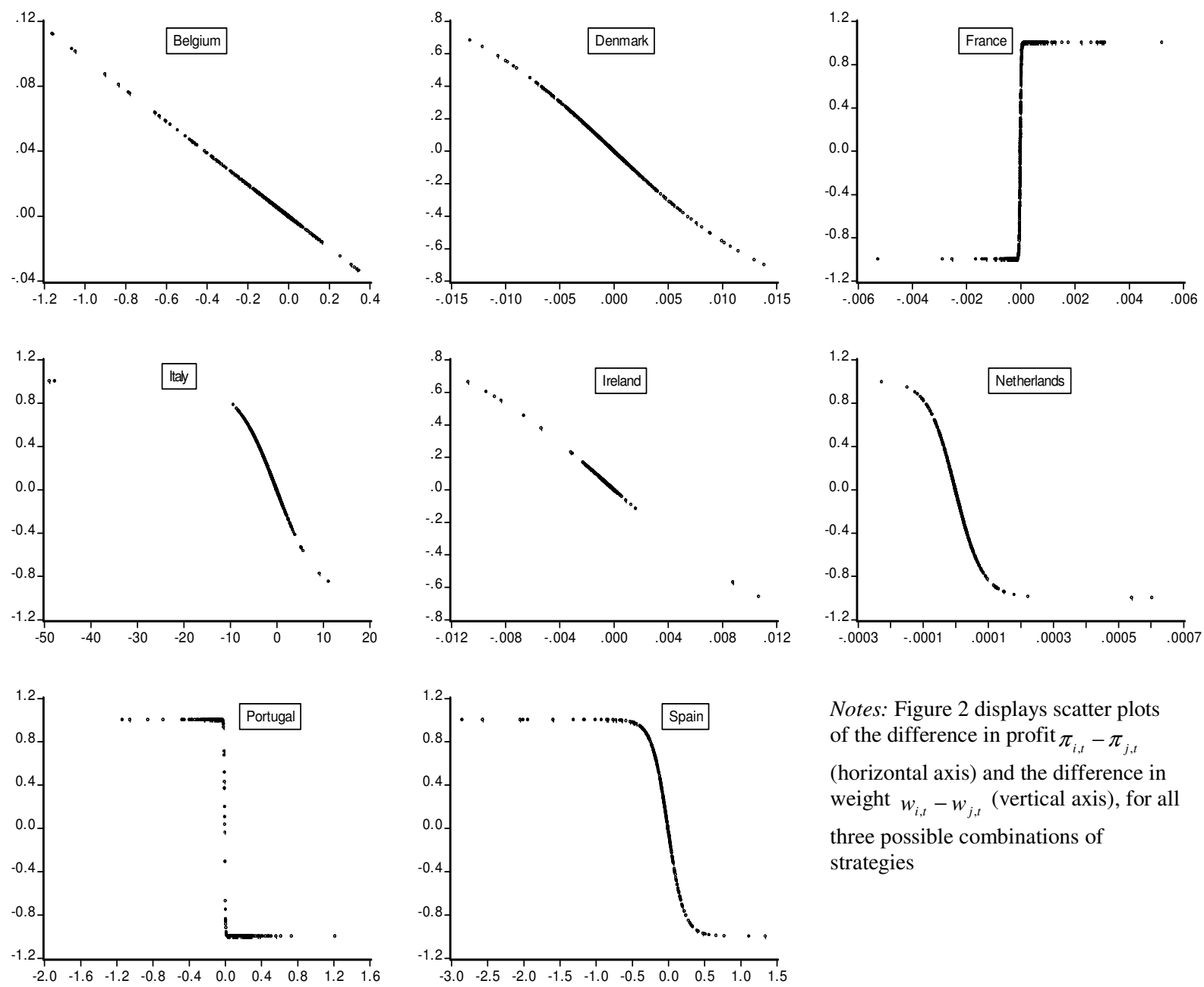

Notes: Figure 2 displays scatter plots of the difference in profit $\pi_{i, t}-\pi_{j, t}$ (horizontal axis) and the difference in weight $w_{i, t}-w_{j, t}$ (vertical axis), for all three possible combinations of strategies 
Figure 3: Simulated Returns
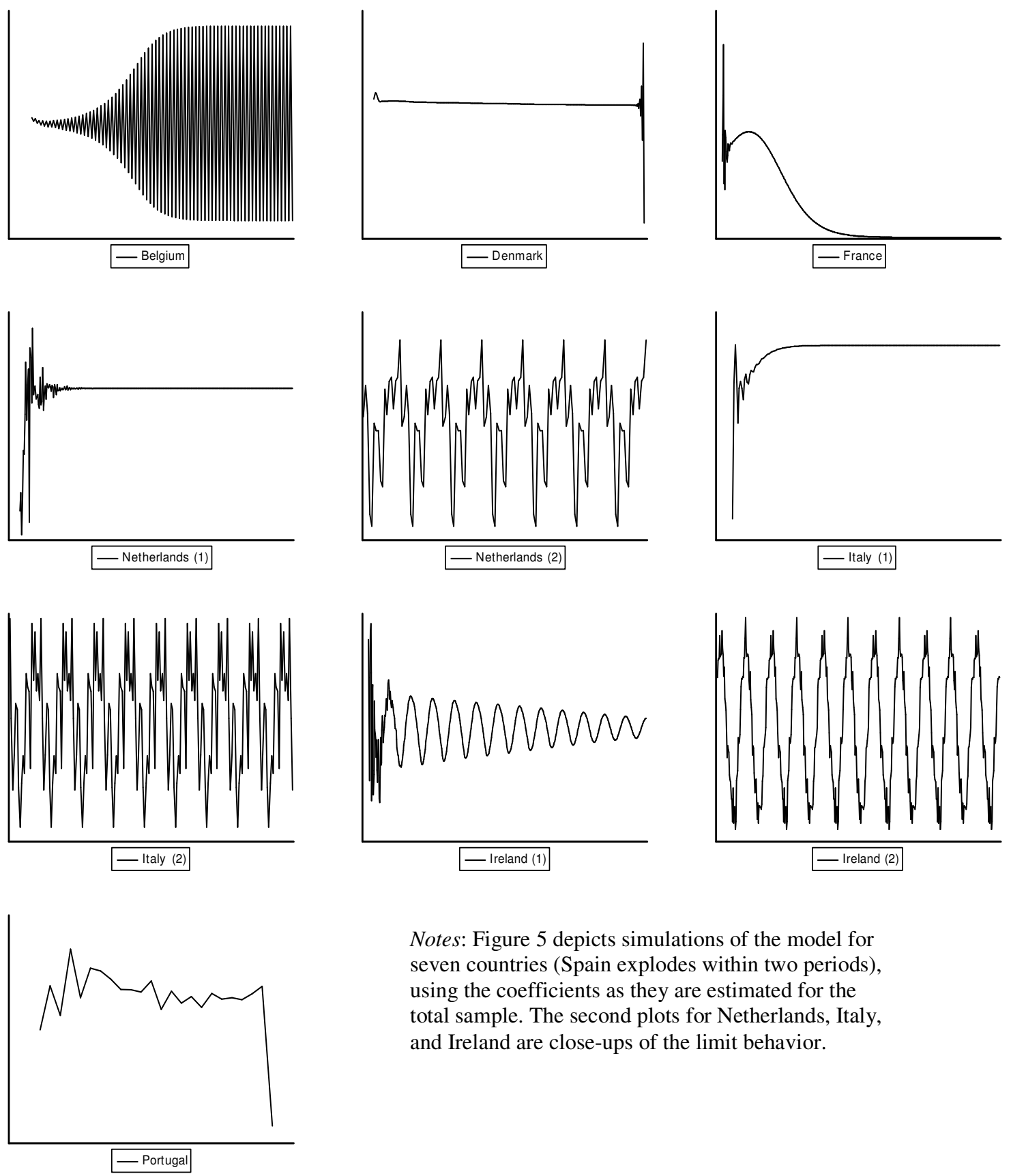

Notes: Figure 5 depicts simulations of the model for seven countries (Spain explodes within two periods), using the coefficients as they are estimated for the total sample. The second plots for Netherlands, Italy, and Ireland are close-ups of the limit behavior. 
Figure 4: Limit cycles
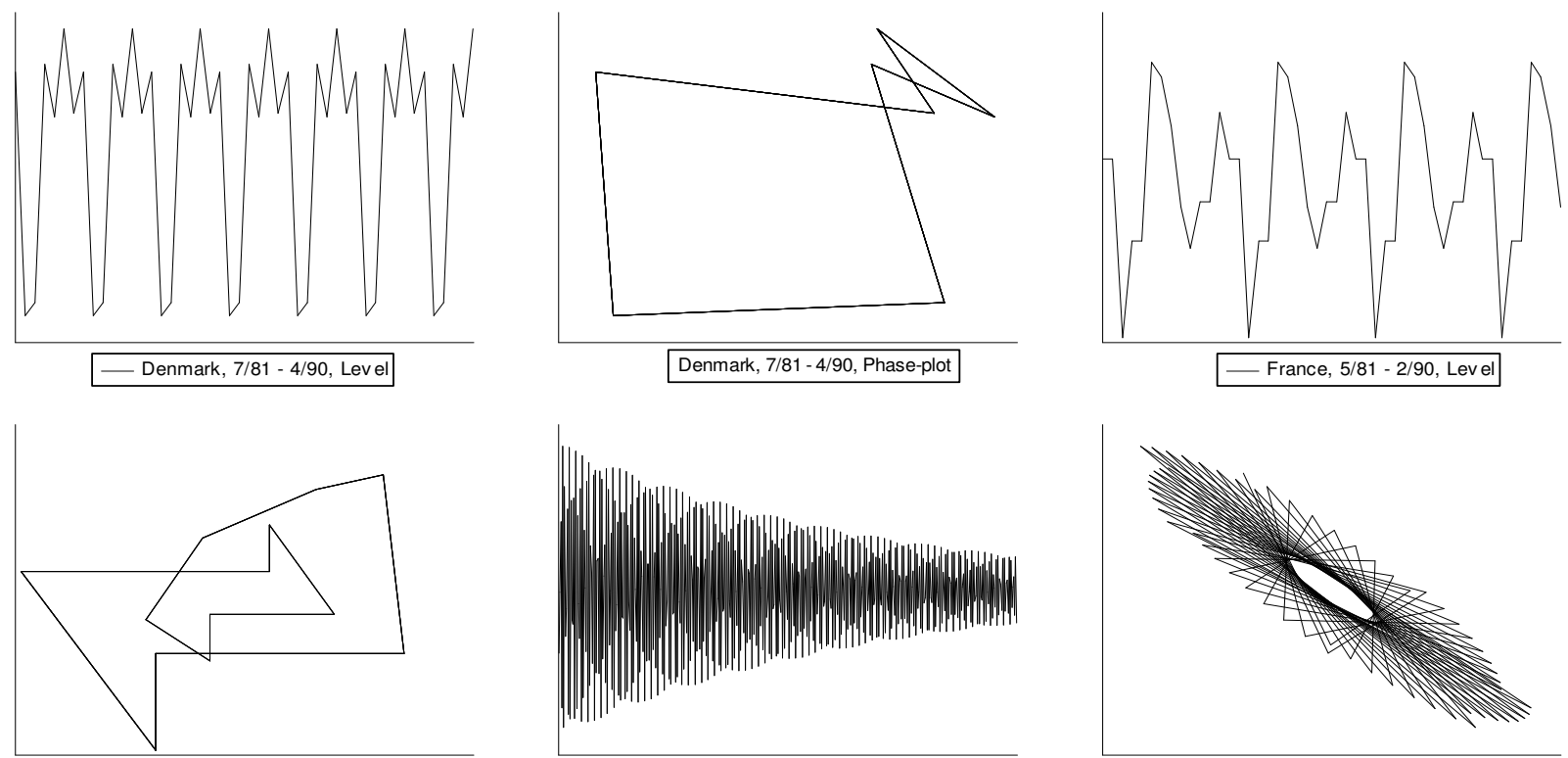

France, 5/81-2/90, Phase-plot
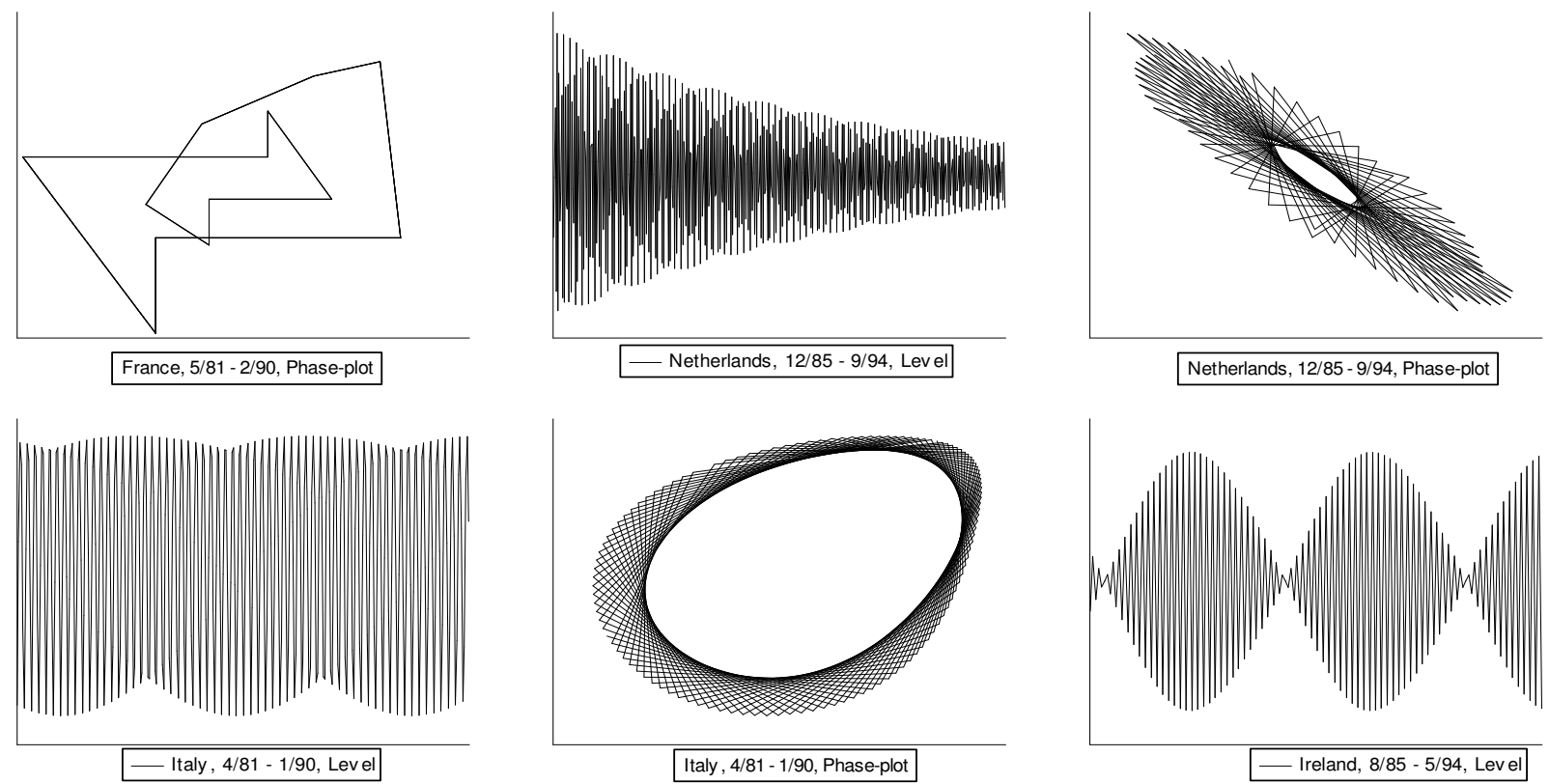

Notes: Figure 6 depicts some examples of higher-order limit cycles and phase plots simulated by the model with coefficients estimated from sub samples. The dates under the figures indicate the sub sample over which the coefficients are estimated. 